\title{
Vitamin D Metabolites: Analytical Challenges and Clinical Relevance
}

\author{
N. Alonso ${ }^{1} \cdot$ S. Zelzer ${ }^{1} \cdot$ G. Eibinger ${ }^{1} \cdot$ M. Herrmann ${ }^{1}$
}

Received: 10 December 2021 / Accepted: 16 February 2022 / Published online: 3 March 2022

(c) The Author(s) 2022

\begin{abstract}
Recent research activities have provided new insights in vitamin D metabolism in various conditions. Furthermore, substantial progress has been made in the analysis of vitamin D metabolites and related biomarkers, such as vitamin D binding protein. Liquid chromatography tandem mass spectrometric (LC-MS/MS) methods are capable of accurately measuring multiple vitamin D metabolites in parallel. Nevertheless, only 25(OH)D and the biologically active form 1,25(OH)2D are routinely measured in clinical practice. While $25(\mathrm{OH}) \mathrm{D}$ remains the analyte of choice for the diagnosis of vitamin D deficiency, $1,25(\mathrm{OH}) 2 \mathrm{D}$ is only recommended in a few conditions with a dysregulated D metabolism. 24,25(OH)2D, free and bioavailable $25(\mathrm{OH}) \mathrm{D}$, and the vitamin D metabolite ratio (VMR) have shown promising results, but technical pitfalls in their quantification, limited clinical data and the lack of reference values, impede their use in clinical practice. LC-MS/MS is the preferred method for the measurement of all vitamin D related analytes as it offers high sensitivity and specificity. In particular, 25(OH)D and 24,25(OH)2D can accurately be measured with this technology. When interpreted together, they seem to provide a functional measure of vitamin $\mathrm{D}$ metabolism beyond the analysis of $25(\mathrm{OH}) \mathrm{D}$ alone. The determination of VDBP, free and bioavailable 25(OH)D is compromised by unresolved analytical issues, lacking reference intervals and insufficient clinical data. Therefore, future research activities should focus on analytical standardization and exploration of their clinical value. This review provides an overview on established and new vitamin D related biomarkers including their pathophysiological role, preanalytical and analytical aspects, expected values, indications and influencing conditions.
\end{abstract}

Keywords Vitamin D $\cdot$ Vitamin D metabolites $\cdot$ Chronic kidney disease $\cdot$ Bone health

\section{Introduction}

Vitamin D deficiency has developed into a global health issue that affects males and females of all age groups. The lack of sun exposure and a limited availability of vitamin D from natural food sources are the main causes of vitamin $\mathrm{D}$ deficiency in modern societies. Other risk factors that can cause or exacerbate vitamin D deficiency are dark skin pigmentation, pregnancy, chronic inflammatory bowel disease with malabsorption, obesity, and advanced age [1]. Acknowledging the global dimension of vitamin $\mathrm{D}$ deficiency has sparked an exponential rise in vitamin $\mathrm{D}$ testing [2-4] and research activities that have resulted in new insights in vitamin $D$ metabolism in various conditions [5-10]. Today, it is well established that vitamin D

M. Herrmann

markus.herrmann@medunigraz.at

1 Clinical Institute of Medical and Chemical Laboratory Diagnostics, Medical University of Graz, Graz, Austria has pleiotropic effects that go far beyond calcium and phosphate metabolism [6]. For example, vitamin D modulates innate and adaptive immunity, cell growth and differentiation, cardiovascular function and hormonal actions $[6,11]$. Furthermore, vitamin D deficiency has been linked to a broad range of clinical conditions including cardiovascular disease, malignancies, autoimmune diseases, neuropsychiatric diseases and endocrinopathies [6, 11]. Substantial progress has also been made in the analysis of vitamin $D$ metabolites and related biomarkers, such as vitamin D binding protein (VDBP). Mass spectrometric methods are capable of measuring multiple vitamin D metabolites in parallel [12-14]. Recently, Jenkinson et al. have developed a method that can measure 13 different vitamin $D$ metabolites, including $25(\mathrm{OH}) \mathrm{D}, 24,25(\mathrm{OH}) 2 \mathrm{D}$ and $1,25(\mathrm{OH}) 2 \mathrm{D}$ [13]. While this method is rather complex, the parallel measurement of $25(\mathrm{OH}) \mathrm{D}$ and $24,25(\mathrm{OH}) 2 \mathrm{D}$ can easily be performed with liquid-chromatography tandem mass spectrometry using standard instrumentation. Several groups have suggested that the parallel measurement of these two metabolites 
provides valuable information beyond $25(\mathrm{OH}) \mathrm{D}$ alone [15-18]. This development has recently been recognized by DEQAS, an external quality assessment program for vitamin D. However, clinical guidelines still unanimously recommend assessing vitamin $\mathrm{D}$ status by the measurement of $25(\mathrm{OH}) \mathrm{D}$. Furthermore, 1,25(OH)2D is only indicated in a very few clinical conditions, such as severe chronic kidney disease, hereditary phosphate-losing disorders, oncogenic osteomalacia, pseudovitamin D-deficiency rickets, vitamin D-resistant rickets, as well as chronic granuloma forming disorders such as sarcoidosis and some lymphomas $[19,20]$. However, recent evidence from experimental and clinical studies merits a closer look into the utility and the analytical standards of traditional and emerging biomarkers of vitamin D metabolism. The aim of this review is to provide structured information on $25(\mathrm{OH}) \mathrm{D}, 1,25(\mathrm{OH}) 2 \mathrm{D}$, 24,25(OH)2D, VDBP and the derived parameters vitamin D metabolite ratio (VMR), free (free-25(OH)D) and bioavailable (bio-25(OH)D) 25(OH)D. Particular focus will be put on the clinical utility, preanalytical, analytical and postanalytical aspects, and interfering factors.

\section{Vitamin D Metabolism}

Vitamin D is not a single compound, but refers to a group of over 50 metabolites, which are derived from cholesterol via a complex cascade of enzymatic and non-enzymatic reactions [19]. Chemically, they are secosteroids that are characterized by a broken bond in one of the steroid rings. The individual metabolites vary greatly in their plasma concentrations and biological activities [21]. Cholecalciferol $\left(\operatorname{vitaminD}_{3}\right)$ and ergocalciferol (vitamin $\mathrm{D}_{2}$ ) are the two main forms of vitamin $\mathrm{D}$. The difference between the two is an additional double bond between carbons 22 and 23 and a methyl group on carbon 24 in the side chain of vitamin $\mathrm{D}_{2}$ [22]. Vitamin $\mathrm{D}_{3}$ is primarily synthesised in human skin under the effect of sunlight. In contrast, vitamin $\mathrm{D}_{2}$ is exclusively obtained from exogenous sources. Many food items, such as fatty fish, liver oil, and egg yolk, contain vitamin $\mathrm{D}_{2}$ and $\mathrm{D}_{3}$ so that the diet contributes 10-20\% to the vitamin D supply of humans [23-25]. Higher amounts of vitamin D can be obtained from fortified foods, such as milk and margarine, or vitamin supplements [26].

Circulating vitamin $D_{2}$ and $D_{3}$ are activated by two hydroxylation reactions that occur in the liver and the kidneys. The hepatic cytochromes P450 CYP2R1 (microsomal) and CYP27A1 (mitochondrial) hydroxylate vitamin $\mathrm{D}_{2}$ and $\mathrm{D}_{3}$ at carbon 25 resulting in the production of $25(\mathrm{OH}) \mathrm{D}$, the most abundant vitamin D metabolite in blood, which is still inactive. Renal CYP27B 1 attaches the second hydroxygroup in position 1 forming active $1,25-(\mathrm{OH})_{2} \mathrm{D}$ [27]. In addition to the kidneys, CYP27B1 is also expressed in many other cell types so that $1,25-(\mathrm{OH})_{2} \mathrm{D}$ can be produced by most extra-renal tissues, where it has primarily autocrine or paracrine function. However, this extra-renal $1,25-(\mathrm{OH})_{2} \mathrm{D}$ synthesis contributes little to the circulating concentration of this metabolite [28]. Vitamin D degradation is predominantly driven by CYP24A1, which metabolises $25(\mathrm{OH}) \mathrm{D}$ to 24,25-dihydroxy-vitamin $\mathrm{D}\left[24,25\left(\mathrm{OH}_{2} \mathrm{D}\right)\right]$ and $1,25(\mathrm{OH})_{2} \mathrm{D}$ to $1,24,25$-trihydroxy-vitamin $\mathrm{D}\left[1,24,25(\mathrm{OH})_{3} \mathrm{D}\right][27]$. In the circulation, all vitamin $\mathrm{D}$ metabolites are bound to vitamin D binding protein (DBP), albumin and lipoproteins.

The C3 hydroxyl group of $25(\mathrm{OH}) \mathrm{D}_{2}$ and $25(\mathrm{OH}) \mathrm{D}_{3}$ can be converted to beta orientation resulting in the formation of 3-epi-25(OH) $\mathrm{D}_{3}, 3$-epi-25(OH) $\mathrm{D}_{2}$. It is believed that this irreversible modification is catalysed by the enzyme 3-epimerase (C-3 epimerisation pathway), which also epimerizes $1 \alpha, 25(\mathrm{OH})_{2} \mathrm{D}_{3}$ and $1 \alpha, 25(\mathrm{OH})_{2} \mathrm{D}_{2}$. Similar to the non-epimerized metabolites, also 3-epi-25(OH) $\mathrm{D}_{3}$, and 3-epi-25(OH) $\mathrm{D}_{2}$ can be further hydroxylized by $1 \alpha$-hydroxylase forming 3-epi-1 $\alpha, 25(\mathrm{OH})_{2} \mathrm{D}_{3}$ and 3-epi-1 $\alpha, 25(\mathrm{OH})_{2} \mathrm{D}_{2}$. So far, 3-epimerase has been identified in the endoplasmatic reticulum of liver, bone and skin [29, 30]. In serum from adult humans, the concentration of 3-epi$25(\mathrm{OH}) \mathrm{D}_{3}$ varies between 1 and $25 \%$ [31]. Children appear to have markedly higher proportion of 3 -epi-25(OH) $\mathrm{D}_{3}$ reaching up to $60 \%$ [32]. With the methods that are commonly used in medical laboratories, the concentrations of all other 3-epimers are too low to be detected. In a study from Shah et al. the mean concentrations of 3-epi-25(OH) $\mathrm{D}_{3}$, and 3-epi-25(OH) $\mathrm{D}_{2}$ were $6.1 \mathrm{nmol} / \mathrm{L}$ and $1.1 \mathrm{nmol} / \mathrm{L}$, respectively. The role of vitamin $\mathrm{D} 3$-epimers in health and disease is still a matter of debate as most of our knowledge is derived from in vitro studies. Apparently, 3-epi-25(OH)D has low affinity for VDBP (36-46\% compared with $25(\mathrm{OH})$ D) and VDR (2-3\%), which explains at least partly the low serum concentration. At present it is believed that 3-epi$25(\mathrm{OH}) \mathrm{D}$ does not adequately reflect vitamin $\mathrm{D}$ status and thus its separate measurement is not recommended. Existing knowledge indicates that $1 \alpha, 25(\mathrm{OH})_{2} \mathrm{D}_{3}$ harbours a lower biological activity and has a markedly lower affinity to the VDR than $1 \alpha, 25(\mathrm{OH})_{2} \mathrm{D}_{3}$. Also, its ability to stimulate intestinal calcium absorption is significantly reduced [33-35]. PTH suppression, however, was detected at similar rates as $1,25(\mathrm{OH})_{2} \mathrm{D}_{3}$ (reviewed in [32]).

\section{5(OH)D}

\section{Role of the Marker}

The inactive prohormone $25(\mathrm{OH}) \mathrm{D}$ represents the main reservoir and transport form of vitamin $\mathrm{D}$. The generation of $25(\mathrm{OH}) \mathrm{D}$ from pro-vitamin $\mathrm{D}_{3}$ is catalyzed by CYP27A, a 25-hydroxylase encoded by the CYP2Rl gene 
[36]. As the most abundant vitamin D metabolite in blood, $25(\mathrm{OH}) \mathrm{D}$ includes the two forms $25(\mathrm{OH}) \mathrm{D}_{2}$ and $25(\mathrm{OH})$ $\mathrm{D}_{3}$ [37]. Hydroxylation of $25(\mathrm{OH}) \mathrm{D}$ in position 1 is mediated by CYP27B1 and results in the formation of active $1,25(\mathrm{OH})_{2} \mathrm{D}$. However, this alpha-hydroxylation occurs on demand, primarily in the kidneys, under the control of parathyroid hormone (PTH). Consequently, the serum concentration of $1,25(\mathrm{OH})_{2} \mathrm{D}$ is kept within the reference range over a wide concentration range of $25(\mathrm{OH}) \mathrm{D}$ and does not reflect vitamin $\mathrm{D}$ stores. In fact, individuals with a low serum $25(\mathrm{OH}) \mathrm{D}$ concentration often have a high-normal or raised $1,25(\mathrm{OH}) 2 \mathrm{D}$ concentration due to a compensatory induction of CYP27B1. Therefore, current guidelines unanimously recommend $25(\mathrm{OH}) \mathrm{D}$ as the preferred indicator of the body's vitamin D stores.

People with dark skin have 30-40\% lower 25(OH)D serum concentrations than Caucasians but comparable or higher bone mineral density (BMD) and lower fracture risk [38]. Furthermore, lower serum 25(OH)D concentrations in blacks are not associated with higher PTH concentrations, lower BMD or increased fracture risk [39-42]. This conundrum is at least partly explained by a high prevalence $(>90 \%)$ of the GC1F haplotype of VDBP (rs7041-T/ rs4588-C) in blacks, whereas the GC1S haplotype of VDBP (rs7041-G/rs4588-C) is dominant in Caucasians [43]. While carriers of the GC1F and the GC1S haplotypes show comparable VDBP concentrations [43] they differ in their affinity for most vitamin D species, which contributes to the different $25(\mathrm{OH}) \mathrm{D}$ concentrations. However, the availability of free vitamin D for metabolism is not affected. Berg et al. have shown that blacks and whites with comparable serum PTH concentrations also have a comparable VMR despite substantially lower 25(OH)D levels [44]. Other factors that contribute to lower $25(\mathrm{OH}) \mathrm{D}$ concentrations in blacks include adiposity and skin pigmentation. A recent report from an international expert panel stated that no one factor alone could fully explain the vitamin D paradox in Black Americans. In addition, blacks have no skeletal benefits from high doses of vitamin D supplementation [45].

\section{Pre-analytical Considerations}

The concentration of $25(\mathrm{OH}) \mathrm{D}$ can be assessed in both, serum and plasma, with similar results [46]. A low biological variability $[47,48]$ in combination with rather high concentrations in the nM range and a long in vitro half-life make $25(\mathrm{OH}) \mathrm{D}$ a robust biomarker that can reliably be measured by clinical laboratories $[14,19,20]$. A recent study from Denmark has shown that the in vivo half life depends on the individual $25(\mathrm{OH}) \mathrm{D}$ concentration and the vitamin $\mathrm{D}$ receptor $(V D R)$ gene polymorphism rs2228570 [49]. In individuals with a 25(OH)D start concentration between 68 and $213 \mathrm{nmol} / \mathrm{L}$, mean half-life was 89 days, whereas lower concentrations were associated with a half-life between 149 and 199 days. The longer half-live at lower 25(OH)D concentrations may be caused by storage mobilisation, changed catabolism or increased intestinal absorption. In addition, the $V D R$ gene polymorphism rs2228570 may explain up to $88 \%$ of the observed variation with the genotype GG having a 120 days shorter half-life than the genotype AA/ AG. Stability studies have shown that $25(\mathrm{OH}) \mathrm{D}$ is stable in whole blood for up to $24 \mathrm{~h}$ when kept at room temperature (RT) [50]. Also, storage of serum for up to $72 \mathrm{~h}$ at RT or refrigerated at $6{ }^{\circ} \mathrm{C}$ has negligible effects on $25(\mathrm{OH}) \mathrm{D}$. Good short term stability of serum $25(\mathrm{OH}) \mathrm{D}$ at RT has also been reported by Zelzer $\mathrm{S}$ et al. [17]. Long-term stability at $-20{ }^{\circ} \mathrm{C}$ and $-80{ }^{\circ} \mathrm{C}$ is generally good. In an own study, we were able to demonstrate that changes do not exceed $15 \%$ after 2 months [17]. Recently, Cavalier et al. reported only minor changes of $25(\mathrm{OH}) \mathrm{D}$ after 5 years of storage at $-80{ }^{\circ} \mathrm{C}$, which are most likely the result of sample concentration rather than degradation [51]. Long-term storage appears to have the least effect on $25(\mathrm{OH}) \mathrm{D}$ measured by LC-MS/MS, whereas samples from renal and pregnant patients may show substantial differences when analysed by immunoassay. Importantly, freezing and thawing of plasma and serum samples does not affect the $25(\mathrm{OH}) \mathrm{D}$ concentration [52]. Also, centrifugation temperature has no substantial effect on the $25(\mathrm{OH}) \mathrm{D}$ concentration $[53,54]$. Importantly, serum and plasma samples for the measurement of $25(\mathrm{OH})$ $\mathrm{D}$ should always be stored in the dark. While short term UV-irradiation has little impact on the 25(OH)D concentration, prolonged sun exposure reduces $25(\mathrm{OH}) \mathrm{D}$ by more than $50 \%$ [54].

\section{Analytical Considerations}

$25(\mathrm{OH}) \mathrm{D}$ is a challenging analyte due to its strong binding to VDBP and other carriers, the need of measuring $25(\mathrm{OH}) \mathrm{D}_{2}$ and $25(\mathrm{OH}) \mathrm{D}_{3}$ in an equimolar fashion, the coexistence of multiple chemically related molecules that may cross-react, and common matrix effects, such as heterophilic antibodies or changes in protein composition [19, 20]. Medical laboratories employ different methods for the measurement of $25(\mathrm{OH}) \mathrm{D}$ in serum and plasma with automated immunoassays, ELISAs and LC-MS/MS being the most frequently used. Radioimmunoassays (RIA) and high-performance liquid chromatography (HPLC) have been widely used in the past, but due to a broad range of alternatives they play a marginal role in today's practice. From an analytical point of view, the available methods can be divided in those with and without complete removal of proteins and lipids by strong organic solvents prior to analysis. The first group includes LC-MS/MS, HPLC and, RIAs whereas the second group comprises automated immunoassays. As automated immunoassay-analysers 
cannot use such organic solvents, they employ alternative strategies to release $25(\mathrm{OH}) \mathrm{D}$ from its carriers. However, they have an inferior dissociation efficacy. The strategies that are used by immunoassay manufacturers to separate $25(\mathrm{OH}) \mathrm{D}$ from its carriers are optimized for the expected matrix composition. In situations where the matrix is altered, such as in pregnant women, patients with chronic kidney disease or individuals with a polymorphic variant of $V D B P$, these approaches may be less efficient and thus introduce analytical bias. In contrast, the organic solvents used in LC-MS/MS are strong enough to precipitate all proteins and detach all vitamin $\mathrm{D}$ metabolites from their carriers [55, 56]. Consequently, automated immunoassays are characterized by a variable analytical performance. In external quality assurance programs, the means of commonly used automated immunoassays show differences of up to $20 \mathrm{nmol} / \mathrm{L}$ in the clinically relevant range. Standardization of the 25(OH)D measurement has been a major step forward. With the help of the standard reference materials (SRM) 972 and 972a, developed by the National Institute of Standardization (NIST), and validated reference measurement procedures (RMP) from the University of Gent [57] and the Centre of Disease Control [58] it is possible to accurately determine the $25(\mathrm{OH}) \mathrm{D}$ concentration in serum and plasma samples. As these RMPs are not suitable for clinical laboratories, the Vitamin D Standardization and Certification Program (VDSCP) has been developed with the aim to align the results of different methods to this reference system [59]. Today, 38 methods are listed at the CDC homepage as being VDSCP certified (https://www.cdc.gov/labstandards/vdscp_parti cipants.html). However, the main weakness of VDSCP is that certification depends on the mean bias obtained on a standard set of samples, regardless of the scatter that these samples produce around the target values. In other words, a wide scatter can produce a similar mean bias than a narrow scatter, as long as the individual values are distributed equally around the target values. Therefore, Wise et al. have proposed the percentage of samples with a bias $\leq 10 \%$ as a better criterion for accuracy [60]. While the different standardization efforts have clearly improved the comparability of $25(\mathrm{OH}) \mathrm{D}$ results obtained with automated immunoassays, external quality assurance programs still show unsatisfactory variability. Numerous laboratories have acknowledged the intrinsic variability of automated immunoassays and switched to LC-MS/MS with electrospray ionisation [61] as the gold standard for the quantification of $25(\mathrm{OH}) \mathrm{D}$. This technology is suitable for the analysis of serum, heparin and EDTA samples [62]. It can accurately measure $25(\mathrm{OH}) \mathrm{D}_{2}$ and $25(\mathrm{OH}) \mathrm{D}_{3}$. Currently, $20 \%$ of all participants of the DEQAS program use LC-MS/MS for the measurement of 25(OH)D. This group is consistently well aligned to the target values and copes best with interferences from other vitamin D metabolites and matrix effects.

All LC-MS/MS methods require a more or less complex pre-analytical sample preparation that cleans the sample and extracts vitamin D metabolites through protein precipitation, liquid-liquid extraction and sometimes derivatisation [40]. Regardless of the pre-analytical sample preparation, thoroughly validated LC-MS/MS methods are consistently capable of producing accurate results [17, 62]. For example, Zhang et al. validated a highly specific LC-MS/MS method for the simultaneous quantification of $25(\mathrm{OH}) \mathrm{D}_{2}$ and $25(\mathrm{OH}) \mathrm{D}_{3}$ in serum and plasma [62]. Using a combination of methanol precipitation and liquid-liquid extraction by heptane, they were able to obtain a $72 \%$ recovery with a coefficient of variation $(\mathrm{CV})<7.05 \%$. The results were well aligned to the Vitamin D External Quality Assessment Scheme (DEQAS) LC-MS/MS method mean values, but about $9 \%$ higher than the commonly used DiaSorin Liasson assay. However, it should be mentioned that LC-MS/ MS methods for the measurement of $25(\mathrm{OH}) \mathrm{D}$ also have disadvantages, such as a (semi)manual sample preparation, and the need of expensive instrumentation and experienced staff. In addition, they are not yet suitable for high throughput. Nevertheless, first fully automated solutions are already available.

From the analytical point of view, 3 -epi- $25(\mathrm{OH}) \mathrm{D}_{3}$ coelutes and has identical mass as $25(\mathrm{OH}) \mathrm{D}_{3}$, and they can only be separated by high resolution chromatography [63]. Considering the ongoing controversy about the biological relevance of vitamin $\mathrm{D} 3$-epimers in health and disease the separate measurement of 3-epi- $25(\mathrm{OH}) \mathrm{D}_{3}$ is not recommended. In addition, most 25(OH)D automated immunoassays do not cross-react with 3-epi-25(OH)D so that they do not represent a relevant issue in clinical practice. Only in children, the higher 3-epi-25(OH)D concentrations may eventually result in a misclassification of vitamin D status, when measured with one of the few $25(\mathrm{OH}) \mathrm{D}$ methods that are interfered by $\mathrm{C} 3$-epimers, such as protein-binding assay.

\section{Reference Values}

Typically, clinical laboratories provide their results with a reference range that comprises the values between the 2.5 th and the 97.5 th percentile of a healthy reference cohort. For several reasons, 25(OH)D results should not be interpreted on the basis of such a reference range. The circulating $25(\mathrm{OH}) \mathrm{D}$ concentration is subject to pronounced seasonal variation of $20-30 \%$ with the highest values in summer and autumn [64]. In 74,235 serum samples from Northern Italy that were collected over a two-year period and analysed by a validated LC-MS/MS method, the $2.5^{\text {th }}$ and $97.5^{\text {th }}$ percentile spanned a rather wide range from 12 to $159 \mathrm{nmol} / \mathrm{L}$. Amongst 2000 healthy Austrian blood donors the traditional 
reference interval was $28.5-136 \mathrm{nmol} / \mathrm{L}$ (unpublished data). However, within the traditional reference interval of $25(\mathrm{OH})$ $\mathrm{D}$, higher concentrations of this metabolite were associated with improved blood biomarker concentrations of calcium homeostasis and bone turnover. In addition, within the reference range, higher $25(\mathrm{OH}) \mathrm{D}$ concentrations are also associated with a lower risk of bone fractures [65-67]. Valcour et al. have shown that PTH continuously decreases with increasing concentrations of $25(\mathrm{OH}) \mathrm{D}$ and that there is no threshold above which this relationship plateaus [68]. The same applies to other conditions, such as stroke, cardiovascular disease, diabetes mellitus and autoimmune disease [69-73]. Considering that the risk for numerous clinical conditions substantially varies across the reference interval, clinical cut-offs are recommended for the interpretation of serum 25(OH)D results. Several scientific societies have developed practice guidelines that propose $25(\mathrm{OH}) \mathrm{D}$ cut-offs on the basis of clinical risk [74]. Most guidelines distinguish between sufficiency, insufficiency and deficiency [37, $75,76]$. Some guidelines also provide cut-offs from severe deficiency to toxicity as summarised in Table 1 [74, 77-82]. These cut-offs apply to bone health, osteoporosis, fracture risk and general health. The First International conference on Controversies in Vitamin D established that levels of 25(OH)D below $12 \mathrm{ng} / \mathrm{mL}(30 \mathrm{nmol} / \mathrm{L})$ were associated with an increased risk of rickets and osteomalacia, while concentrations between 50 and $125 \mathrm{nmol} / \mathrm{L}$ are sufficient to maintain bone health [83]. However, commonly used 25(OH)D cut-off values apply primarily to Caucasians and Asians. People with dark skin have 30-40\% lower 25(OH)D serum concentrations than Caucasians but comparable or higher bone mineral density (BMD) and lower fracture risk [38].

\section{Indications}

Measurement of serum 25(OH)D is recommended for the diagnosis of vitamin D deficiency [37, 78, 81]. Individuals at increased risk of vitamin D deficiency are those with fragility fractures, chronic kidney disease, malabsorption, and abnormalities of calcium and phosphate metabolism [84]. Determining serum $25(\mathrm{OH}) \mathrm{D}$ is also useful for the differential diagnosis of rickets, osteomalacia, and the monitoring of vitamin D supplementation. Finally, 25(OH)D should be determined in patients with suspected hypervitaminosis D and intoxication. When considering measuring vitamin $\mathrm{D}$ in the context of various non-bone related disease, it should be kept in mind that reverse causality and residual confounding cannot be excluded. Rather than being an actionable causal factor for chronic diseases, vitamin D deficiency could simply be the result of an underlying condition that alters vitamin D metabolism, or a lifestyle that is associated with poor health and micronutrient deficiencies. Therefore, the value of measuring 25(OH)D for the assessment and management of non-bone-related diseases is a matter of ongoing debate and not yet recommended.

\section{Influence of 25(OH)D in Pathological Conditions}

Most 25(OH)D in serum is bound to VDBP (85\%) and albumin (15\%) [85]. Variations in the serum concentrations of these carriers lead to corresponding changes of $25(\mathrm{OH})$ D. The hepatic 25-hydroxylation of vitamin D was long believed to be unregulated [36]. However, recent studies suggest that both age and metabolism can modulate CYP27A activity. Aged humans and animals are characterized by a lower expression of CYP2R1 than their young counterparts and thus they are less responsive to vitamin D supplementation [86]. As vitamin D can be sequestered in adipose tissue [87], it is not surprising that nutrition and body composition also modulate CYP2R activity $[87,88]$.

Pregnancy causes a small increase in $25(\mathrm{OH}) \mathrm{D}$ which is at least partly driven by an increase in VDBP [89]. However, not all studies found a significant changes of serum $25(\mathrm{OH})$ $\mathrm{D}$ in pregnant women $[90,91]$. Figueiredo et al. showed that the serum $25(\mathrm{OH}) \mathrm{D}$ concentration during pregnancy is influenced by seasonal effects [92]. Women starting pregnancy during winter showed rising $25(\mathrm{OH}) \mathrm{D}$ concentrations, whereas women who fell pregnant in summer exhibited no increase. Interestingly, the placenta possesses the principal enzymes of vitamin D metabolism including CYP2R1, CYP27B1 and CYP24A1 and may thus be involved in the regulation of circulating 25(OH)D levels [93]. Maternal $25(\mathrm{OH}) \mathrm{D}$ can crosses the placenta and is the exclusive vitamin D source of the foetus reaching cord blood levels between 75 and $100 \%$ of the maternal value [94].

Anti-epileptic drugs, such as phenobarbital, carbamazepine, phenytoin and valproate, are known to accelerate vitamin $\mathrm{D}$ catabolism and thus lower the serum $25(\mathrm{OH}) \mathrm{D}$
Table 1 Vitamin D guidelines for different regions

\begin{tabular}{llllllll}
\hline & Global* & Europe* & USA* & Brazil* & Japan* & Australia* & Gulf Region* \\
\hline Toxicity & $>250$ & $>500$ & $>150$ & & & & \\
Sufficiency & $50-250$ & $50-225$ & $>75$ & $75-250$ & $>75$ & $\geq 50$ & $>75$ \\
Insufficiency & $30-75$ & $50-75$ & $50-75$ & $50-74$ & $50-75$ & $30-49$ & $50-75$ \\
Deficiency & $<50-25$ & $<50$ & $<50$ & $<50$ & $<50$ & $<29$ & $<50$ \\
\hline
\end{tabular}

*All values are reported as $\mathrm{nmol} / \mathrm{L}$ 
concentration [82]. Binding of these drugs to the pregnane $\mathrm{X}$ receptor increases $25(\mathrm{OH}) \mathrm{D}$ catabolism by an induction of CYP3A4 and CYP24A1. The preganane $\mathrm{X}$ receptor is a nuclear receptor that shares homologies with the VDR. In order to mitigate the risk of vitamin D deficiency, reduced BMD and increased fracture risk, patients on long-term treatment with anti-epileptic drugs should receive a prophylactic vitamin D supplementation and have their serum $25(\mathrm{OH}) \mathrm{D}$ concentration monitored.

Patients with CKD at stages 3 and 4 usually present deficiency of vitamin $\mathrm{D}$, a marker of poor prognosis [95]. Similarly, $60-80 \%$ of pre-dialysis children with CKD also have low levels of 25(OH)D [96]. In addition to low serum 25(OH)D levels, CKD patients are also characterized by elevated phosphate and FGF-23 concentrations. The adverse impact of CKD on calcium and phosphate metabolism is associated with secondary hyperparathyroidism. However, the management of vitamin D status in nephrology is still a matter of ongoing debate. In any case, CKD patients with 25(OH)D deficiency should always be treated, regardless of PTH [95]. Vitamin D deficiency in Stages 1 to 3a follow general population recommendations. Later stages are treated with calcitriol or vitamin D analogues, depending on patient characteristics [97].

Obese and bariatric surgery patients frequently present with vitamin $\mathrm{D}$ deficiency. Fat soluble vitamin $\mathrm{D}$ can be sequestered in adipose tissue resulting in reduced circulating $25(\mathrm{OH}) \mathrm{D}$ concentrations. Instead, bariatric surgery compromises the absorption of dietary vitamin $\mathrm{D}[98,99]$. To prevent adverse skeletal effects, vitamin D deficiency should be diagnosed and corrected prior to bariatric surgery [100]. However, it may be difficult to normalize $25(\mathrm{OH}) \mathrm{D}$ and PTH in these patients.

Vitamin D levels have also been investigated in cancer and cardiovascular disease (CVD). Observational studies identified an increased CVD mortality only in vitamin D deficient subjects, but not individuals with normal 25(OH) D serum concentrations. Large randomized intervention studies, such as the VITAL study (25,000 individuals aged 50 years or older treated with $2000 \mathrm{IU} /$ day of vitamin D and $1 \mathrm{~g} /$ day of omega-3 fatty acid for over 5 years) [101] and the VIDA study (5000 individuals over 50 years of age treated with an initial dose of 200,000 IU and then 100,000 IU/ month of vitamin D for 3.3 years) [102] failed to show any beneficial effect of vitamin D supplementation on the incidence of invasive cancer or the appearance of CVD. The lacking effect of vitamin D supplementation on CVD and cancer incidence is further supported by meta-analyses that pooled randomised clinical trials (reviewed in [103]). However, in line with the observational studies mentioned before, a reduced risk was found in vitamin D deficient subjects. Although existing intervention studies failed to show reductions in CVD and cancer risk, the results may be biased due to some pitfalls, such as the lack of appropriate controls that are completely naive to oral vitamin D intake via the food or de-novo synthesis by the skin [103]. Based on existing observational and intervention studies, measurement of serum $25(\mathrm{OH})$ is primarily useful to identify vitamin $\mathrm{D}$ deficient individuals, where supplementation appears to have beneficial effects on CVD and cancer risk. It should be kept in mind that the interpretation of $25(\mathrm{OH}) \mathrm{D}$ results in CVD and cancer patients could be complicated by residual confounding and reverse causality, as vitamin D insufficiency could be the result of poor health and disease specific alterations of vitamin D metabolism [104]. Therefore, the quantification of additional vitamin $\mathrm{D}$ metabolites could aid the assessment of vitamin D status in these patients.

Due to its immune-modulatory function, vitamin D has also been investigated in COVID-19 patients. Observational studies have shown that individuals with vitamin D deficiency have an increased risk to develop severe COVID-19 (as reviewed in [105]). However, a retrospective study by Mangge et al. failed to find any association between $25(\mathrm{OH})$ $\mathrm{D}_{3}, 25(\mathrm{OH}) \mathrm{D}_{2}, 24,25(\mathrm{OH})_{2} \mathrm{D}_{3}$ and $\left.25,26(\mathrm{OH})_{2} \mathrm{D}_{3}\right)$ and clinical outcome measures, such as recovery rate, death or the need of respiratory support [106]. In the absence of COVID19-specific prevention studies, some information can be derived from vitamin D supplementation studies that measured the incidence of other infectious respiratory diseases, especially in children. Again, while these studies did not show significant effects in individuals with adequate $25(\mathrm{OH})$ D concentrations, those with vitamin D deficiency benefitted from vitamin D supplementation. As these studies used primarily historical $25(\mathrm{OH}) \mathrm{D}$ analyses, their results may be biased. Based on the limited evidence available, the role of vitamin D in SARS-CoV2-infected patients remains controversial. However, there is some support for a correction of vitamin D deficiency in SARS-CoV2-infected patients to prevent severe disease and adverse outcome.

\section{Measurement of 1,25(OH)2D}

\section{Role of the Marker}

$1,25(\mathrm{OH})_{2} \mathrm{D}$ is the active form of vitamin $\mathrm{D}$ that is produced through $1 \alpha$-hydroxylation of $25(\mathrm{OH}) \mathrm{D}$. This hydroxylation step is catalysed by CYP27B1 (1 $\alpha$-hydroxylase) and occurs mainly in the kidneys. Consequently, the circulating $1,25(\mathrm{OH})_{2} \mathrm{D}$ concentration primarily reflects renal production. Meanwhile, it is well established that many other cells and tissues, such as monocytes, macrophages, dendritic cells, osteoblasts, and keratinocytes, also express $1 \alpha$-hydroxylase and thus are cable of producing $1,25(\mathrm{OH})_{2} \mathrm{D}$ locally [107]. However, $1,25(\mathrm{OH})_{2} \mathrm{D}$ that is produced by extra-renal tissues has mainly auto- and paracrine functions 
and adds little to the serum level [108, 109]. The biological activity of $1,25(\mathrm{OH})_{2} \mathrm{D}$ is mediated by binding to the VDR [5], a nuclear receptor that binds specific DNA sequences located at different genomic regions (vitamin D response elements), to subsequently modulate the expression of the respective target genes [110].

With concentrations in the lower pmol/L range, $1,25(\mathrm{OH})_{2} \mathrm{D}$ circulates at much lower levels than $25(\mathrm{OH})$ D. The half-life of $1,25(\mathrm{OH})_{2} \mathrm{D}$ is only $4-6 \mathrm{~h}$, which makes serum levels rather volatile. Both metabolites have similar physical and chemical properties [111-113], but unlike $25(\mathrm{OH}) \mathrm{D}, 1,25(\mathrm{OH})_{2} \mathrm{D}$ does not reflect the storage levels of vitamin D in the body [114]. Supplementation of vitamin D increases serum $25(\mathrm{OH}) \mathrm{D}$, but has no measurable effect on serum $1,25(\mathrm{OH})_{2} \mathrm{D}[115,116]$. Some studies suggest that there is no relationship between both metabolites $[117,118]$. In fact, it appears that $1,25(\mathrm{OH})_{2} \mathrm{D}$ is produced on demand depending on the cellular need, whereas $25(\mathrm{OH}) \mathrm{D}$ reflects the stores that are available for utilization.

The main role of $1,25(\mathrm{OH})_{2} \mathrm{D}$ is regulating blood calcium levels through intestinal absorption, renal reabsorption and release from bone stores [119]. When the calcium intake is low, PTH increases the synthesis of $1,25(\mathrm{OH})_{2} \mathrm{D}$, which subsequently activates the transport of calcium from the intestinal lumen to the blood by upregulating TRPV6 and other genes, such as $S 100 G, A T P 2 B 1$, and $C L D N 2$, in the intestine [120]. When calcium intake increases, PTH secretion is reduced leading to a decrease in $1,25(\mathrm{OH})_{2} \mathrm{D}$ and activation of a paracellular route, a non-saturable and passive transport through the intercellular space between adjacent cells, which is also modulated by $1,25(\mathrm{OH})_{2} \mathrm{D}$ (reviewed in [121]). Therefore, $1,25(\mathrm{OH})_{2} \mathrm{D}$ is a key regulator of bone mineralisation [122]. The release of calcium from bone is accompanied by an increased secretion of fibroblast growth factor 23 (FGF23) by osteocytes, which, upon binding to Klotho, inhibits 1-alpha hydroxylase and ultimately reduces the renal synthesis of $1,25(\mathrm{OH})_{2} \mathrm{D}$ [123].

In addition to the regulation of calcium homeostasis, $1,25(\mathrm{OH})_{2} \mathrm{D}$ also supports bone formation by increasing the osteoblastic expression of alkaline phosphatase, osteocalcin and ostepontin [124]. Furthermore, it stimulates bone resorption by increasing osteoclastogenesis and osteoclast activity [125]. $1,25(\mathrm{OH})_{2} \mathrm{D}$ is also involved in the regulation of cell proliferation, differentiation and apoptosis [126]. Experimental evidence from $1 \alpha$-hydrolase knockout mice suggests that low levels of $1,25(\mathrm{OH})_{2} \mathrm{D}$ increase age-related bone loss by activating senescence pathways, like p16/p19 [127]. An adequate supply with $1,25(\mathrm{OH})_{2} \mathrm{D}$ could thus preserve bone health by activating an anti-ageing mechanism [128].

In addition to its role in bone, $1,25(\mathrm{OH})_{2} \mathrm{D}$ also attenuates the inflammatory response of monocytes and macrophages and increases the expression of anti-inflammatory compounds like IL-10. In contrast, the secretion of proinflammatory cytokines like IL-1b, IL-6, TNF $\alpha$, RANKL and $\mathrm{COX} 2$ is reduced by $1,25(\mathrm{OH})_{2} \mathrm{D}$ [129]. These immunomodulatory effects may explain the $1,25(\mathrm{OH})_{2} \mathrm{D}$-mediated risk reduction of autoimmune diseases like multiple sclerosis [130]. Blood pressure, insulin secretion and insulin sensitivity are also modified by calcitriol [131-133]. These associations could, at least partially, be due to the regulatory role of $1,25(\mathrm{OH})_{2} \mathrm{D}$ in calcium homeostasis. Also, the renin-angiotensin axis is influenced by $1,25(\mathrm{OH})_{2} \mathrm{D}$, which may explain the association with hypertension (reviewed in [134]).

Recent evidence suggests that $1,25(\mathrm{OH})_{2} \mathrm{D}$ is also linked to the gut microbiome. High serum concentrations of $1,25(\mathrm{OH})_{2} \mathrm{D}$, but not $25(\mathrm{OH}) \mathrm{D}$, are strongly correlated with alpha and beta diversity, especially with butyrate-producing bacteria, like Firmicutes. Based on these results, it has been hypothesized that butyrate-producing bacteria could stimulate the local production of $1,25(\mathrm{OH})_{2} \mathrm{D}$ by dendritic cells in the colon [135]. In this context, a previous animal model lacking $V D R$ and $C Y P 27 B 1$ also showed impaired levels of $1,25(\mathrm{OH})_{2} \mathrm{D}$ and reduced number of Firmicutes [136].

\section{Pre-analytical Considerations}

$1,25(\mathrm{OH})_{2} \mathrm{D}$ has similar physical and chemical properties as $25(\mathrm{OH}) \mathrm{D}$; however, it is more hydrophilic, has shorter halflife (around $6 \mathrm{~h}$ ), and it is found in blood at very low concentrations (in the range of picomol/L) [137]. Altogether, it presents similar challenges as $25(\mathrm{OH}) \mathrm{D}$ for analytical detection, but requires a substantially higher sensitivity [46]. Because of these characteristics, results are more volatile.

\section{Analytical Considerations}

Measurement of $1,25(\mathrm{OH})_{2} \mathrm{D}$ in serum or plasma is considerably more challenging than $25(\mathrm{OH}) \mathrm{D}$ due to is very low concentration. In addition, a standard reference material and a reference measurement procedure are lacking. The first assay for the measurement of $1,25(\mathrm{OH})_{2} \mathrm{D}$ was a radioreceptor binding assay, where $1,25(\mathrm{OH})_{2} \mathrm{D}$ in the sample displaced tritiated hormone from a cytosol-chromatin receptor preparation isolated from chick small intestine [138]. With this assay, Brumbaugh et al. were able to determine a human plasma concentration of $60 \mathrm{pg} / \mathrm{ml}$ in patients with renal disease. In the following years competitive protein binding assays [139], RIAs [140], enzyme immune assays (EIAs) [141], HPLC [142-144], gas chromatographymass spectrometry (GC-MS) [145] and LC-MS/MS [146] methods were developed. A comprehensive overview of available methods and their characteristics is provided by several review articles [147, 148]. Until recently, commercial RIAs were widely used to determine $1,25(\mathrm{OH})_{2} \mathrm{D}$ in 
clinical laboratories. With the development of fully automated immunoassays $[141,149]$ this picture has changed. In $2017,75 \%$ of the participants in the DEQAS program used automated immunoassays, $15 \%$ manual immunoassays and $9 \%$ LC-MS/MS. However, the comparability of automated immunoassays with LC-MS/MS methods is not ideal [150]. Even within the individual method groups substantial variability exists. In this context, different calibration procedures are a common source of variability [151]. LC-MS/ MS methods adopt different strategies to cope with the very low analyte concentration. Vitamin D metabolite profiling, and in particular measurement of $1,25(\mathrm{OH})_{2} \mathrm{D}$, typically requires a dual column system, where the first column serves for analyte enrichment and the second one for separation. Other methods include a preanalytical immunopurification step [149, 152, 153] whereas others do not [154]. The antibody used for immunopurification is supposed to enrich the target analyte $1 \alpha-25$-dihydroxyvitamin D and thus reduces interferences from isobaric compounds, such as $1 \beta$-25-dihydroxyvitamin D [84]. Another way to improve analytical sensitivity is the derivatization of $1,25(\mathrm{OH})_{2} \mathrm{D}$ [46]. PTAD (4-phenyl-1,2,4-triazoline-3,5-dione) is the most frequently used derivatization agent for this purpose. Also the ionization mode impacts the analytical performance of LC-MS/MS methods [63]. While derivatization methods typically use electrospray ionization (ESI), atmosphericpressure chemical ionisation (APCI) is a valid alternative that achieves good results without the need of derivatization [63]. However, in the absence of standardization it is not possible to conclude that one method is more accurate than another.

\section{Reference Values}

In contrast to $25(\mathrm{OH}) \mathrm{D}$, where results are interpreted on the basis of clinical cut-offs, method specific reference intervals are recommended for $1,25(\mathrm{OH})_{2} \mathrm{D}$. In healthy adults, the reference interval for the IDS RIA is $43-168 \mathrm{pmol} / \mathrm{L}$, whereas the automated IDS iSYS immunoassay has a reference interval of 63-228 pmol/L [141]. A different reference interval of $59-159 \mathrm{pmol} / \mathrm{L}$ has been reported for LC-MS/MS. However, these methods typically measure only $1,25(\mathrm{OH})_{2} \mathrm{D}_{3}$. For a separate quantitation of $1,25(\mathrm{OH})_{2} \mathrm{D}_{2}$ most methods are not sensitive enough as the circulating level has been reported to be $<17 \mathrm{pmol} / \mathrm{L}$ [155]. In addition, immunoassays may be interfered by chemically related vitamin D metabolites that cross-react.

Blood levels of $1,25(\mathrm{OH})_{2} \mathrm{D}$ in children are higher than in adults. The following paediatric reference intervals have been established by Higgins et al. on the CALIPER cohort using the DiaSorin Liason XL method: $77-471 \mathrm{pmol} / \mathrm{L}$ between 0 and 1 year, 113-363 pmol/L between 1 and 3 years, and 108 $-246 \mathrm{pmol} / \mathrm{L}$ for children older than 3 years. The CALIPER cohort includes 377 Canadian children and adolescents [156]. For other methods, paediatric reference intervals have not been reported.

\section{Indications}

To date, the clinical utility of $1,25(\mathrm{OH})_{2} \mathrm{D}$ is insufficiently understood, which limits its clinical use. Serum levels of $1,25(\mathrm{OH})_{2} \mathrm{D}$ have little or no relationship to vitamin D stores but rather are regulated by PTH. Measurement of $1,25(\mathrm{OH})_{2} \mathrm{D}$ is helpful in the investigation of patients with unexplained hypercalcaemia, sarcoidosis, granulomatous disorders, pseudo-vitamin D deficiency, rickets, tumour-induced osteomalacia, hyperparatiroidism, and CYP24A1 deficiency [20]. Moreover, measurement of this vitamin D metabolite can be helpful to differentiate between FGF23-dependent and -independent phosphopenic rickets [157]. Levels of $1,25(\mathrm{OH})_{2} \mathrm{D}$ are usually low in $\mathrm{CKD}$, but its measurement has only been recommended when patients present severe and progressive hyperparathyroidism [158].

\section{Influence of 1,25(OH)2D in Pathological Conditions}

Low serum levels of $1,25(\mathrm{OH})_{2} \mathrm{D}$ are observed in CKD and hypoparathyroidism [159]. In contrast, elevated serum concentrations occur in patients with sarcoidosis and tuberculosis. Antimycotic drugs, such as ketoconazole reduce the circulating $1,25(\mathrm{OH})_{2} \mathrm{D}$ concentration and have successfully been used to treat tuberculosis-associated hypercalcaemia [160, 161]. Pregnancy increases the serum $1,25(\mathrm{OH})_{2} \mathrm{D}$ concentration due to an induction of renal $1 \alpha$-hydroxylase activity [162]. In addition, $1 \alpha$-hydroxylase and the VDR are both expressed in the placenta. However, the function of placental $1,25(\mathrm{OH})_{2} \mathrm{D}$ synthesis is poorly understood. Serum $1,25(\mathrm{OH})_{2} \mathrm{D}$ levels are also higher in African individuals of all age-groups [163, 164], which may be due to increased PTH levels in this population [165]. However, the differences in the metabolism of vitamin, calcium and phosphate are insufficiently understood. Mutations of genes involved in $1,25(\mathrm{OH})_{2} \mathrm{D}$ metabolism also influence circulating $1,25(\mathrm{OH})_{2} \mathrm{D}$ levels (reviewed in [121]). These mutations cause rare hereditary metabolic bone conditions, like hereditary vitamin D-resistant rickets $(V D R)$, vitaminD-dependent rickets type 1A (CYP27B1), type 1B (CYP2RI) or idiopathic infantile hypercalcemia $(C Y P 24 A 1)$. Mutations of the cell surface metalloproteinase $P H E X$ cause X-linked hypophosphataemia (XLH), which is characterized by lownormal $1,25(\mathrm{OH})_{2} \mathrm{D}$ concentrations [166]. 
Measurement of 24,25(OH) ${ }_{2} \mathrm{D}$ and Calculation of the $24,25(\mathrm{OH})_{2} \mathrm{D} / 25(\mathrm{OH})$ D Ratio

\section{Clinical Utility}

$24,25(\mathrm{OH})_{2} \mathrm{D}$ is the principal catabolite of $25(\mathrm{OH}) \mathrm{D}$ that is formed through the action of CYP24A1 when sufficient amounts of $25(\mathrm{OH}) \mathrm{D}$ are available. Under physiological conditions the serum concentration of $24,25(\mathrm{OH})_{2} \mathrm{D}$ ranges at approximately $10 \%$ of the $25(\mathrm{OH}) \mathrm{D}$ concentration. Normally, $25(\mathrm{OH}) \mathrm{D}$ and $24,25(\mathrm{OH})_{2}$ are highly correlated $[167,168]$. Therefore, the isolated measurement of $24,25(\mathrm{OH})_{2}$ does not provide superior information when compared to $25(\mathrm{OH}) \mathrm{D}$. However, the simultaneous determination of both metabolites has been found useful to identify patients with reduced CYP24A1 activity. Affected individuals are characterized by a reduced ratio between $24,25(\mathrm{OH})_{2} \mathrm{D}$ and $25(\mathrm{OH}) \mathrm{D}$ [17]. This ratio is also known as vitamin D metabolite ratio (VMR). CYP24A1 loss-offunction mutations cause infantile hypercalcemia (IIH) and represent a genetic risk factor for serious adverse effects in response to vitamin D supplementation [169]. In hypercalcaemic patients, the parallel measurement of both vitamin D metabolites and calculation of the VMR allows distinguishing CYP24A1 deficiency from other causes of hypercalcaemia, such as vitamin D intoxication, granulomatous disease, Williams-Beuren syndrome or mutations of the $S L C 34 A 1$ gene $[18,170]$. Therefore, $24,25(\mathrm{OH})_{2} \mathrm{D}$ and $25(\mathrm{OH}) \mathrm{D}$ can be helpful in guiding genetic testing in patients with inherited hypercalcaemia.

In addition to the rather rare conditions mentioned before, Cavalier et al. have proposed the simultaneous quantitation of $24,25(\mathrm{OH})_{2} \mathrm{D}$ and $25(\mathrm{OH}) \mathrm{D}$ as a dynamic measure of vitamin D metabolism that aids the identification of individuals with functional vitamin D deficiency [15]. In a cohort of 1200 infants, children, adolescent and young adults, the vast majority of individuals with low $25(\mathrm{OH}) \mathrm{D}$ had $24,25(\mathrm{OH})_{2} \mathrm{D}$ concentrations below the lower level of quantitation. With increasing $25(\mathrm{OH}) \mathrm{D}$ levels, the percentage of individuals such a low $24,25(\mathrm{OH})_{2} \mathrm{D}$ concentration decreased and was negligible when serum $25(\mathrm{OH}) \mathrm{D}$ exceeded $21 \mathrm{ng} / \mathrm{ml}(52,5 \mathrm{nmol} / \mathrm{L})$. Based on these results, the authors concluded that this cut-off corresponds to biochemical vitamin D sufficiency. However, Cavallier et al. have also shown that different individuals with the same $25(\mathrm{OH}) \mathrm{D}$ concentration can have detectable or undetectable $24,25(\mathrm{OH})_{2} \mathrm{D}$ levels, suggesting that they are not equally vitamin D sufficient. This observation questions the use of a fixed 25(OH)D cut-off and suggests that an individual evaluation of the vitamin D status based on a simultaneous analysis of $24,25(\mathrm{OH})_{2} \mathrm{D}$ and $25(\mathrm{OH})$ $\mathrm{D}$ might be more appropriate. Also, in black individuals, the parallel determination of both metabolites does better reflect the individual vitamin $\mathrm{D}$ status than the measurement of 25(OH)D alone. On average, blacks have a $40 \%$ lower $25(\mathrm{OH}) \mathrm{D}$ serum concentration, which is at least partially due to ethnic differences in the prevalence of common genetic VDBP polymorphisms [38]. Recent evidence from a cohort study of elderly community-dwelling individuals has shown that the VMR was associated with the risk of hip fracture whereas $25(\mathrm{OH}) \mathrm{D}$ was not [171]. In addition, higher $24,25(\mathrm{OH})_{2} \mathrm{D}$, but not VMR, was associated with a higher bone mineral density (BMD). The management of renal patients may also benefit from the measurement of $24,25(\mathrm{OH})_{2} \mathrm{D}$. In addition to a decreased production of $1,25(\mathrm{OH})_{2} \mathrm{D}$, also vitamin $\mathrm{D}$ catabolism is impaired in patients with chronic kidney disease [172]. The Seattle Kidney Study has shown that patients with a $24,25(\mathrm{OH})_{2} \mathrm{D}$ serum concentration below the cohort median of $2.4 \mathrm{ng} / \mathrm{ml}$ had a significantly lower eGFR and an increased risk of mortality. Moreover, the inverse correlation of $24,25(\mathrm{OH})_{2} \mathrm{D}$ with $\mathrm{PTH}$ was stronger than that of $25(\mathrm{OH}) \mathrm{D}$ or $1,25(\mathrm{OH}) 2 \mathrm{D}$.

Last, but not least, the VMR has also been proposed as an interesting tool to guide vitamin D supplementation at an individual level [173]. However, in existing vitamin D supplementation studies, neither $24,25(\mathrm{OH})_{2} \mathrm{D}$ nor VMR predicted the increase in serum $25(\mathrm{OH}) \mathrm{D}$ better than the baseline $25(\mathrm{OH})$ concentration $[118,174,175]$. In addition, neither $24,25(\mathrm{OH})_{2} \mathrm{D}$ nor VMR predicted the biological effect of vitamin D supplementation on bone and mineral metabolism better than 25(OH)D [176]. However, as most participants had detectable $24,25(\mathrm{OH})_{2} \mathrm{D}$ in serum, it cannot be excluded that they were vitamin D sufficient, which may have limited the diagnostic potential of this analyte. So far, no study compared the response of vitamin $\mathrm{D}$ supplementation in individuals with and without measureable concentrations of $24,25(\mathrm{OH})_{2} \mathrm{D}$, but comparable serum $25(\mathrm{OH}) \mathrm{D}$ concentrations.

Current guidelines do not yet recommend the measurement of $24,25(\mathrm{OH})_{2} \mathrm{D}$ in clinical practice. However, existing studies suggest that this practice should be changed. The determination of $24,25(\mathrm{OH})_{2} \mathrm{D}$ and calculation of the VMR are helpful in the differential diagnosis of patients with hypercalcaemia and seem to improve risk prediction in conditions where vitamin D catabolism is impaired. In addition, the simultaneous measurement of $25(\mathrm{OH}) \mathrm{D}$ and $24,25(\mathrm{OH})_{2} \mathrm{D}$ may help to individualize the assessment of patients' vitamin D status. In contrast, neither $24,25(\mathrm{OH})_{2} \mathrm{D}$ nor VMR can predict the response to vitamin D supplementation better than 25(OH)D. 


\section{Preanalytical Considerations}

$24,25(\mathrm{OH})_{2} \mathrm{D}$ and $25(\mathrm{OH}) \mathrm{D}$ share similar chemical properties. Both compounds are very stable in serum and can thus be kept for up to 2 months at temperatures between $+25^{\circ} \mathrm{C}$ and $-80^{\circ} \mathrm{C}[17,177]$. For long-term storage samples should be frozen. More than 2 freeze-and-thaw cycles should be avoided as the serum $24,25(\mathrm{OH})_{2} \mathrm{D}$ concentration decreases by more than $20 \%$. So far, the effect of light exposure and sample matrix on the $24,25(\mathrm{OH})_{2} \mathrm{D}$ serum concentration has not been studied systematically. However, it is prudent to protect samples from light exposure. The influence of patient related preanalytical factors, such as food intake, menstrual cycle or sunlight exposure has not been studied systematically. However, it can be expected that in line with $25(\mathrm{OH})$ $\mathrm{D}$, vitamin D supplementation and sunlight exposure will increase the synthesis of $24,25(\mathrm{OH})_{2} \mathrm{D}$.

\section{Analytical Considerations}

Measurement of $24,25(\mathrm{OH})_{2} \mathrm{D}$ is typically performed by LC-MS/MS. Although this technology is considered the gold standard for the measurement of vitamin D and its metabolites, an interlaboratory assay comparison by Wise et al. has shown substantial systemic differences of up to $36 \%$ [178]. In order to improve the comparability of $24,25(\mathrm{OH})_{2} \mathrm{D}$ results, a standard reference material [179, 180] and a reference method [181] have been developed. In addition, first EQA programs have included this analyte in their portfolio [182]. The efficacy of these measures has been demonstrated by a recent comparison study of two inhouse LC-MS/MS methods [16]. Both methods were properly validated and underwent regular proficiency testing. So far, immunoassays or other analytical methods for the measurement of this lowly concentrated analyte have yet not been developed.

\section{Reference Values}

So far, two studies have determined references ranges for the serum concentration of $24,25(\mathrm{OH})_{2} \mathrm{D}$ and the VMR using validated LC-MS/MS methods [183, 184]. In 1996, Tang et al. found an average $24,25(\mathrm{OH})_{2} \mathrm{D}$ serum concentration of $5.7 \pm 3.4 \mathrm{nmol} / \mathrm{L}$ and calculated a reference interval (2.5th-97.5th percentile) of 1.1.-13.5 nmol/L in healthy young army recruits (504 females and 1492 males) with a mean age of 23 years [184]. The diagnostic cut-off for vitamin D sufficiency (serum 25(OH)D $>50 \mathrm{nmol} / \mathrm{L}$ ) was $>4.2 \mathrm{nmol} / \mathrm{L}$. Dirks et al. established a serum $24,25(\mathrm{OH})_{2} \mathrm{D}$ reference interval in 92 middle-aged adults that ranged from 0.4 to $8.9 \mathrm{nmol} / \mathrm{L}$ [183]. Both studies calculated the VMR as $25(\mathrm{OH}) \mathrm{D} / 24,25(\mathrm{OH})_{2} \mathrm{D}$ and reported reference intervals of 10-33 [184] and 7-23 [183], respectively.
In line with these results, an earlier study from Ketha et al. reported a VMR reference interval of 7-35, which was obtained in 91 adults with an age range of 28-86 years [185]. It should be mentioned that not all laboratories calculate the VMR in the same way, while some use the formula $25(\mathrm{OH}) \mathrm{D} / 24,25(\mathrm{OH})_{2} \mathrm{D}$, others do it the other way round $24,25(\mathrm{OH})_{2} \mathrm{D} / 25(\mathrm{OH}) \mathrm{D}$, which provides totally different figures. Moreover, the VMR is further limited by the fact the two vastly different numbers are divided by each other and thus small changes in $24,25(\mathrm{OH})_{2} \mathrm{D}$ result in a great change in VMR. Furthermore, imprecision of this ratio is affected by the imprecision of the two methods.

\section{Measurement of Vitamin D Binding Protein (VDBP) and Calculation of Free and Bioavailable 25(OH)D}

\section{Role of the Marker}

VDBP is a highly polymorphic protein with over 100 isoforms that is encoded by the VDBP gene on chromosome $4 q 12-q 13$. Structurally, the protein is closely related to albumin and alpha-fetoprotein [85]. It is mainly produced in the liver, but animal studies suggest that it can also be expressed by other tissues, such as kidney, testis, and adipose tissue [186]. The expression of VDBP is regulated by estrogens, which show higher concentrations during pregnancy and upon oral contraception [85].

As mentioned above, VDBP binds approximately $85 \%$ and albumin $15 \%$ of all circulating vitamin D metabolites [85]. Less than $0.1 \%$ of all $25(\mathrm{OH}) \mathrm{D}$ in the plasma of normal individuals is free. Similar to other steroid hormones, it is believed that only the free fraction can enter the cells to bind the cytosolic VDR. The free hormone hypothesis is supported by the observation that lacking VDBP does not necessarily cause functional vitamin $\mathrm{D}$ deficiency despite very low serum concentrations of $25(\mathrm{OH}) \mathrm{D}$ and $1,25(\mathrm{OH})_{2} \mathrm{D}$ [187-189]. In addition to its transport function of vitamin D metabolites, VDBP has also other functions including the renal megalin/cubilin-mediated reuptake of $25(\mathrm{OH}) \mathrm{D}$ in the kidneys, the scavenging of actin after muscular damage, neutrophil recruitment, complement 5a-mediated chemotaxis, fatty acid binding and formation of VDBP-Macrophage Activating Factor V (DBP-MAF) [85, 187]. For example, significant amounts of actin are released from damaged cells in response to trauma, sepsis, liver trauma, acute lung injury, preeclampsia, surgery, and burns. Upon polymerization, filamentous F-actin in combination with coagulation factor Va can promote disseminated intravascular coagulation and multiorgan failure. Through binding to VDBP, actin is rapidly cleared by the liver, lungs and spleen, thus preventing polymerization. 
Based on the free hormone hypothesis [190] is has been proposed that free $25(\mathrm{OH}) \mathrm{D}$ might be a better marker than total $25(\mathrm{OH}) \mathrm{D}$ to reflect a patient's current vitamin D status $[38,191]$. For example, patients with liver cirrhosis have a $100 \%$ higher median of free $25(\mathrm{OH}) \mathrm{D}$ than unaffected controls, despite lower total 25(OH)D concentrations. Interestingly, these patients develop osteoporosis rather than osteomalacia, as it would be expected for vitamin D deficient patients with a low total 25(OH)D concentration [192]. In contrast, pregnant women have lower free $25(\mathrm{OH}) \mathrm{D}$ concentrations than non-pregnant controls [193]. Due to existing inconsistencies, the applicability of the free hormone hypothesis to vitamin $\mathrm{D}$ is still a matter of ongoing debate [153]. In contrast to other steroid hormones, the active metabolite $1,25(\mathrm{OH})_{2} \mathrm{D}$ is feedback regulated and the concentration of free hormone is so low that it may be insufficient for passive diffusion across the cell membrane and effective receptor binding [153]. In addition, it cannot be excluded that the megalin-dependent uptake of the VDBP$25(\mathrm{OH}) \mathrm{D}$ complex into cells is limited to the proximal renal tubule. For example, a vitamin D-dependent expression megalin and cubilin has been found in several other epithelia including placenta, parathyroid glands, pneumocytes, and epididymal epithelial cells [93, 194-196].

Considering the much lower affinity of $25(\mathrm{OH}) \mathrm{D}$ to albu$\min \left(\mathrm{K}_{\mathrm{a}}=7 \times 10^{8} / \mathrm{M}\right)$ than to $\operatorname{VDBP}\left(\mathrm{K}_{\mathrm{a}}=6 \times 10^{5} / \mathrm{M}\right)$, it is believed that albumin-bound $25(\mathrm{OH}) \mathrm{D}$ can easily dissociate from the protein and is thus available for metabolism. This concept has led to the term bioavailable $25(\mathrm{OH}) \mathrm{D}$, which refers to all the circulating $25(\mathrm{OH}) \mathrm{D}$ that is not tightly bound to VDBP [197]. Several studies have used bioavailable $25(\mathrm{OH}) \mathrm{D}$ rather than free $25(\mathrm{OH}) \mathrm{D}[38,198-200]$.

Free [201] and bioavailable [38] 25(OH)D are calculated from total 25(OH)D, albumin and VDBP:

Free $25(\mathrm{OH}) \mathrm{D}=\frac{\text { Total } 25(\mathrm{OH}) \mathrm{D}}{\left(\mathrm{k}_{\text {Albumin }}+\mathrm{k}_{\mathrm{VDBP}}\right)}$

Total 25(OH)D = free 25(OH)D + albumin-bond 25(OH)D + VDBP-bond 25(OH)D

$\mathrm{k}_{\text {Albumin }}=6 \times 10^{5} / \mathrm{M}$

$\mathrm{k}_{\mathrm{VDBP}}=7 \times 10^{8} / \mathrm{M}$

Bioavailable $25(\mathrm{OH}) \mathrm{D}=\left(\mathrm{k}_{\mathrm{Alb}} \times \mathrm{Alb}+1\right) \times$ free $25(\mathrm{OH}) \mathrm{D}$

For accuracy, the measurements of 25(OH)D and VDBP are best performed by LC-MS/MS. The polymorphic nature of VDBP results in numerous variants of the protein with Gc1f and Gc1s and Gc2 being most common. These variants are believed to differ in their affinity for $25(\mathrm{OH}) \mathrm{D}$ [202, 203]. The lowest $k_{\mathrm{VDBP}}$ has been reported for the $1 \mathrm{f} / 1 \mathrm{f}$ variant with $3.6 \times 10^{8} / \mathrm{M}$, whereas $2 / 2$ has supposedly the highest $\mathrm{k}_{\mathrm{VDBP}}$ with $11.2 \times 10^{8} / \mathrm{M}$. However, different affinities of VDBP variants to $25(\mathrm{OH}) \mathrm{D}$ are a matter of ongoing scientific debate [85]. Nevertheless, VDBP haplotypes impact the concentrations of total $25(\mathrm{OH}) \mathrm{D}$, free $25(\mathrm{OH}) \mathrm{D}$, and VDBP. The $2 / 2$ haplotype is associated with the lowest total and free $25(\mathrm{OH}) \mathrm{D}$ concentrations. The lowest free percentage was seen with the 1s/1s haplotype and the highest one with the 1f/1f haplotype. Furthermore, the different Gc alleles affect the response to vitamin D supplementation [204]. The clinical significance of these VDBP variants is insufficiently understood. Existing studies do not show differences in fracture rate [44, 205]. However, significant associations with numerous chronic disease, such as type 1 and 2 diabetes, osteoporosis, chronic obstructive lung disease, inflammatory bowel disease, some malignancies and tuberculosis, have been reported [206, 207].

\section{Preanalytical Considerations}

VDBP is relatively stable. Storing serum for $48 \mathrm{~h}$ at room temperature or refrigerated introduces only a small positive bias of $<10 \%$ [43]. Also, up to 2 freeze-thaw-cycles have no major impact on VDBP. Regarding LC-MS/MS methods, autosampler stability is also acceptable with $<16 \%$ loss during $24 \mathrm{~h}$ in a 96-well plate. In order to minimize the impact of preanalytical factors, samples should be processed rapidly after collection. The distribution of VDBP variants differs substantially between black and white individuals, which has important analytical implications (see below) and impacts free 25(OH)D levels. Haemolysis and lipaemia have also been reported to interfere with the measurement [43]. In addition, free $25(\mathrm{OH}) \mathrm{D}$ is less stable than proteinbound $25(\mathrm{OH}) \mathrm{D}$ and thus requires some precautions for direct measurement. Samples are light-sensitive and should be protected from UV-irradiation. Long term storage should be at $-70{ }^{\circ} \mathrm{C}$ [208]. To mitigate the impact of preanalytical factors on free $25(\mathrm{OH}) \mathrm{D}$, measurement in fresh samples is preferred.

\section{Analytical Considerations}

The measurement of VDBP is challenging and LC-MS/MS is the preferred method for this analyte due to superior sensitivity and specificity [43]. For example, only LC-MS/MS can detect VDBP isoforms. However, LC-MS/MS analyses require experienced staff and expensive equipment, which are not widely available [208]. Immunoassays have been developed as easy-to-use alternative that allow a relatively high throughput. However, the use of immunoassays for 
the quantitation of a highly polymorphic protein, such as VDBP, is problematic, especially when the target epitope(s) are located near the polymorphic region [43]. For example, Henderson CM et al. have shown that assays with a monoclonal capture antibody may react differently with common variants, and thus deliver misleading results [43]. With a monoclonal immunoassay, blacks, which carry predominantly the Gc1f variant, have been reported to have substantially lower VDBP concentrations than whites [38, 209]. When using a validated LC-MS/MS method that can distinguish between VDBP variants, no ethnic differences in VDBP concentration were found. Although polyclonal assays are less influenced by isoforms and other genetic variations, they still deliver largely discrepant results when compared to LC-MS/MS with a median bias of $+50 \%$ [210]. Such differences have great impact on the calculation of free and bioavailable 25(OH)D [209, 211]. Therefore, free and bioavailable $25(\mathrm{OH}) \mathrm{D}$ concentrations should be determined on the basis of accurate VDBP and total $25(\mathrm{OH}) \mathrm{D}$ results obtained with validated LC-MS/MS methods.

The direct quantification of free $25(\mathrm{OH}) \mathrm{D}$ constitutes an analytical challenge, due to its very low concentration ( $0.02 \%$ to $0.09 \%$ of total $25(\mathrm{OH}) \mathrm{D}$ concentration) [193]. Even sensitive LC-MS/MS systems are not sufficient to accurately measure such low concentrations. Therefore, most studies calculate the free $25(\mathrm{OH}) \mathrm{D}$ concentration from measurements of total $25(\mathrm{OH}) \mathrm{D}$, VDBP and albumin. However, the result is strongly dependent on the accuracy of the methods used for total 25(OH)D and VDBP. A comparison of calculated free $25(\mathrm{OH}) \mathrm{D}$ results obtained with four different VDBP immunoassays has shown differences of up to $50 \%$. Direct methods for the measurement of free 25(OH)D have also been developed [212, 213]. Centrifugal ultrafiltration has been described in the 1980s and appears reasonably accurate [212]. However, this method is highly complex and expensive. A recently marketed ELISA from DiaSource showed good agreement with a dialysis-based reference method [213], but low concordance with indirect methods [211, 214]. Amongst 173 healthy women, Deming's regression showed a slope of $0.3 \pm 0.03$, and a correlation coefficient of $0.6 \pm 0.06$.

\section{Expected Values}

To date, reliable reference values for free $25(\mathrm{OH}) \mathrm{D}$ and VDBP have not yet been established, and several ranges have been proposed. Due to the lack of standardization, reference intervals have to be method-specific. In addition, differences between black and white individuals have been reported for some methods, but not for others. When measuring free $25(\mathrm{OH}) \mathrm{D}$ by direct immunoassay in 279 healthy controls with a median age of 36.6 years, $95 \%$ of the results ranged between 0.5 and $8.1 \mathrm{pg} / \mathrm{ml}$, with VDBP concentrations measured by a polyclonal immunodiffusion assay between 190.8 and $395.2 \mu \mathrm{g} / \mathrm{ml}$ [193]. Amongst 2085 participants of the Healthy Aging in Neighbourhoods of Diversity across the Life Span cohort, blacks and whites showed mean \pm standard error concentrations of $168 \pm 3 \mu \mathrm{g} /$ $\mathrm{ml}$ and $337 \pm 5 \mu \mathrm{g} / \mathrm{ml}$, respectively [38]. Bioavailable $25(\mathrm{OH}) \mathrm{D}$-was $2.9 \pm 0.1 \mathrm{ng} / \mathrm{ml}$ in blacks and $3.1 \pm 0.1 \mathrm{ng} / \mathrm{ml}$ in whites. However, VDBP was measured by a monoclonal immunoassay that suffers from variable detection of different VDBP variants. In 173 healthy women, Peris et al. reported free $25(\mathrm{OH}) \mathrm{D}$ concentrations between 2 and $15 \mathrm{pg} / \mathrm{ml}$ using an indirect method whereas directly measured results ranged between 2 and $8 \mathrm{pg} / \mathrm{ml}$ [214]. Zeng et al. determined normal free $25(\mathrm{OH}) \mathrm{D}$ results on the basis of sufficient total $25(\mathrm{OH}) \mathrm{D}$ concentrations and suggested a range between 8.5 and $28.3 \mathrm{pg} / \mathrm{ml}$ (equivalent to 30 and $100 \mathrm{ng} / \mathrm{ml}$ of total $25(\mathrm{OH}) \mathrm{D}$ [74]. In our opinion, this range is rather high. In healthy children, Lopez-Molina et al. calculated that directly measured free $25(\mathrm{OH}) \mathrm{D}$ results above $9.8 \mathrm{pmol} / \mathrm{L}$ (equal to $3.9 \mathrm{pg} / \mathrm{ml})$ correlate best with a total $25(\mathrm{OH}) \mathrm{D}$ concentration $>50 \mathrm{nmol} / \mathrm{L}$ [215].

\section{Indications}

Currently, routine measurement of VDBP, free and bioavailable 25(OH)D are not recommended due to unresolved analytical issues and the lack clinical evidence that supports an additional value beyond the measurement of total $25(\mathrm{OH})$ D. Potential areas of interest for the use of these markers are patients with liver or renal disease, which cause a decreased synthesis or loss of VDBP. Moreover, determining free $25(\mathrm{OH}) \mathrm{D}$ could also be useful for pregnant women or women on hormone therapy, because estrogens can upregulate VDBP levels. In the same line, elderly people could also benefit from assessing this marker since VDBP levels can be altered in this group due to a multifactorial effect $[216,217]$. However, future clinical studies have to clarify the potential value of VDBP, free and bioavailable $25(\mathrm{OH})$ $\mathrm{D}$ in such patients.

\section{Influence of VDBP in Pathological Conditions}

Different variants of VDBP with different affinities for $25(\mathrm{OH}) \mathrm{D}$ influence the measurement of VDBP as well as the determination of free $25(\mathrm{OH}) \mathrm{D}$. As the distribution of VDBP variants changes between blacks and whites, ethnicity needs to be considered when assessing these markers [38]. Based on the method used, differences in VDBP and free $25(\mathrm{OH}) \mathrm{D}$ have been found or not $[38,43,211]$. Changes in estrogen levels, such as in pregnancy, alter the expression of VDBP. Between the second and third trimester, VDBP levels increase up to two-fold. However, these variations are not 
linked to changes in free $25(\mathrm{OH}) \mathrm{D}$, which remains stable or slightly decreases $[85,218,219]$.

Critically ill patients with organ dysfunction also show substantial variation in serum VDBP when compared with normal individuals [220, 221]. Liver diseases, especially at late stages, often cause impaired protein synthesis, resulting in decreasing levels of VDBP and albumin. In turn, free $25(\mathrm{OH}) \mathrm{D}$ is increased in these patients compared to controls [85]. These changes are most pronounced in cirrhotic patients. Renal disease also decreases VDBP levels, via proteinuria and saturation of the maximal transport capacity of the megalin/cubilin system. Consistently, nephrotic patients present low total and free 25(OH)D levels [222]. However, in dialysis patients VDBP levels are comparable with healthy individuals [218]. Despite normal VDBP levels, immunoassays and LC-MS/MS methods vary in the quantitation of $25(\mathrm{OH}) \mathrm{D}$ in dialysis patients. Potential differences may be due to increased urea concentrations that interfere with the release of $25(\mathrm{OH}) \mathrm{D}$ from VDBP, the binding equilibrium or the reagents of immunoassays. In contrast, LC-MS/MS methods are not affected from such interferences.

\section{Conclusion}

The existence of multiple vitamin D metabolites with different biological activities and their binding to VDBP and other carriers makes the assessment of vitamin D status a challenging task. Despite promising results for alternative markers, such as $24,25(\mathrm{OH}) \mathrm{D}$, VMR, free and bioavailable $25(\mathrm{OH}) \mathrm{D}, 25(\mathrm{OH}) \mathrm{D}$ remains the preferred analyte for this purpose. The assessment of $25(\mathrm{OH}) \mathrm{D}$ is recommended for patients with established metabolic bone disease or individuals with an increased risk of developing these conditions, and the monitoring of vitamin D supplementation. For nonbone-related diseases, the determination of $25(\mathrm{OH}) \mathrm{D}$ is not recommended. Despite recent standardization, the accurate measurement of $25(\mathrm{OH}) \mathrm{D}$ remains a critical issue in clinical practice. Properly validated LC-MS/MS methods are preferable due to their high sensitivity, specificity, and robustness for interferences from matrix effects. $1,25(\mathrm{OH})_{2} \mathrm{D}$, $24,25(\mathrm{OH}){ }_{2} \mathrm{D}$ and the VMR provide functional information on vitamin D metabolism and are thus useful for the investigation of rare enzyme defects (24-hydroxylase deficiency) and some other diseases (e.g. sarcoidosis, tuberculosis). The determination of VDBP, free and bioavailable $25(\mathrm{OH}) \mathrm{D}$ is compromised by unresolved analytical issues, the lack of reference intervals and insufficient clinical evidence that justifies their use. Future research should address analytical standardization and explore the clinical value of novel markers of vitamin D metabolism.
Author Contributions $\mathrm{MH}$ conceived the idea; all authors performed the literature search, wrote the manuscript and critically review it.

Funding Open access funding provided by Medical University of Graz. The authors did not receive support from any organisation for the submitted work.

Data availability Availability of data and material is not applicable.

\section{Declarations}

Conflict of interest There is no conflict of interest to declare.

Open Access This article is licensed under a Creative Commons Attribution 4.0 International License, which permits use, sharing, adaptation, distribution and reproduction in any medium or format, as long as you give appropriate credit to the original author(s) and the source, provide a link to the Creative Commons licence, and indicate if changes were made. The images or other third party material in this article are included in the article's Creative Commons licence, unless indicated otherwise in a credit line to the material. If material is not included in the article's Creative Commons licence and your intended use is not permitted by statutory regulation or exceeds the permitted use, you will need to obtain permission directly from the copyright holder. To view a copy of this licence, visit http://creativecommons.org/licenses/by/4.0/.

\section{References}

1. Holick M (2017) The vitamin D deficiency pandemic: approaches for diagnosis, treatment and prevention. Rev Endocr Metab Disord 18:153-165. https://doi.org/10.1007/S11154-017-9424-1

2. Crowe FL, Jolly K, Macarthur C et al (2019) Trends in the incidence of testing for vitamin D deficiency in primary care in the UK: a retrospective analysis of the Health Improvement Network (THIN), 2005-2015. BMJ Open. https://doi.org/10.1136/bmjop en-2018-028355

3. Zhao S, Gardner K, Taylor W et al (2015) Vitamin D assessment in primary care: changing patterns of testing. London J Prim Care (Abingdon) 7:15-22. https://doi.org/10.1080/17571472. 2015.11493430

4. Schumacher LD, Jäger L, Meier R et al (2020) Trends and between-physician variation in laboratory testing: a retrospective longitudinal study in general practice. J Clin Med 9:1-11. https://doi.org/10.3390/jcm9061787

5. Pike JW, Christakos S (2017) Biology and mechanisms of action of the vitamin D hormone. Endocrinol Metab Clin North Am 46:815-843

6. Christakos S, Dhawan P, Verstuyf A et al (2016) Vitamin D: metabolism, molecular mechanism of action, and pleiotropic effects. Physiol Rev 96:365-408. https://doi.org/10.1152/PHYSR EV.00014.2015

7. Girgis CM, Baldock PA, Downes M (2015) Vitamin D, muscle and bone: integrating effects in development, aging and injury. Mol Cell Endocrinol 410:3-10

8. Charoenngam N, Holick MF (2020) Immunologic effects of vitamin d on human health and disease. Nutrients 12:1-28

9. Charoenngam N, Shirvani A, Holick MF (2019) Vitamin D for skeletal and non-skeletal health: what we should know. J Clin Orthop Trauma 10:1082-1093

10. Christakos S, Seth T, Hirsch J et al (2013) Vitamin D biology revealed through the study of knockout and transgenic mouse 
models. Annu Rev Nutr 33:71-85. https://doi.org/10.1146/ ANNUREV-NUTR-071812-161249

11. Muscogiuri G, Mitri J, Mathieu C et al (2014) Mechanisms in endocrinology: vitamin $\mathrm{D}$ as a potential contributor in endocrine health and disease. Eur J Endocrinol 171:R101-R110

12. Tuckey RC, Cheng CYS, Slominski AT (2019) The serum vitamin D metabolome: what we know and what is still to discover. J Steroid Biochem Mol Biol 186:4-21

13. Jenkinson C, Desai R, Slominski AT et al (2021) Simultaneous measurement of 13 circulating vitamin D3 and D2 mono and dihydroxy metabolites using liquid chromatography mass spectrometry. Clin Chem Lab Med 59:1642-1652. https://doi.org/10. 1515/cclm-2021-0441

14. Makris K, Sempos C, Cavalier E (2020) The measurement of vitamin D metabolites: part I-metabolism of vitamin D and the measurement of 25-hydroxyvitamin D. Hormones (Athens) 19:81-96. https://doi.org/10.1007/S42000-019-00169-7

15. Cavalier E, Huyghebaert L, Rousselle O et al (2020) Simultaneous measurement of 25(OH)-vitamin D and 24,25(OH)2-vitamin $\mathrm{D}$ to define cut-offs for CYP24A1 mutation and vitamin D deficiency in a population of 1200 young subjects. Clin Chem Lab Med. https://doi.org/10.1515/CCLM-2019-0996

16. Zelzer S, Le Goff C, Peeters S et al (2021) Comparison of two LC-MS/MS methods for the quantification of 24,25-dihydroxyvitamin D3 in patients and external quality assurance samples. Clin Chem Lab Med. https://doi.org/10.1515/cclm-2021-0792

17. Zelzer S, Meinitzer A, Enko D et al (2020) Simultaneous determination of 24,25- and 25,26-dihydroxyvitamin D3 in serum samples with liquid-chromatography mass spectrometry-a useful tool for the assessment of vitamin D metabolism. J Chromatogr B Anal Technol Biomed Life Sci. https://doi.org/10.1016/j. jchromb.2020.122394

18. Kaufmann M, Schlingmann KP, Berezin L et al (2021) Differential diagnosis of vitamin D-related hypercalcemia using serum vitamin D metabolite profiling. J Bone Miner Res 36:1340-1350. https://doi.org/10.1002/JBMR.4306

19. Herrmann M, Farrell CJL, Pusceddu I et al (2017) Assessment of vitamin D status-a changing landscape. Clin Chem Lab Med $55: 3-26$

20. Altieri B, Cavalier E, Bhattoa HP et al (2020) Vitamin D testing: advantages and limits of the current assays. Eur J Clin Nutr 74:231-247

21. Zerwekh JE (2008) Blood biomarkers of vitamin D status. Am J Clin Nutr. https://doi.org/10.1093/ajcn/87.4.1087s

22. Horst RL, Reinhardt TA, Reddy GS (2005) Vitamin D metabolism. In: Feldman D, Pike JWGF (eds) Vitamin D, 2nd edn. Elsevier Academic Press, London, pp 15-36

23. Ross AC, Taylor CL, Yaktine AL, Del Valle HB (2011) Institute of Medicine (US) Committee to review dietary reference intakes for vitamin D and calcium. In: Dietary reference intakes for calcium and vitamin D. National Academies Press, US. https://doi. org/10.17226/13050

24. Holick MF (2002) Vitamin D: the underappreciated D-lightful hormone that is important for skeletal and cellular health. Curr Opin Endocrinol Diabetes 9:87-98

25. Willett AM (2005) Vitamin D status and its relationship with parathyroid hormone and bone mineral status in older adolescents. Proc Nutr Soc 64:193-203. https://doi.org/10.1079/pns20 05420

26. National Institutes of Health. Office of dietary supplements (2014) Vitamin D. https://ods.od.nih.gov/factsheets/VitaminDHealthProfessional/

27. Jones G, Prosser DE, Kaufmann M (2014) Cytochrome P450-mediated metabolism of vitamin D. J Lipid Res 55:13-31
28. Prentice A, Goldberg GR, Schoenmakers I (2008) Vitamin D across the lifecycle: physiology and biomarkers. Am J Clin Nutr. https://doi.org/10.1093/ajen/88.2.500S

29. Kamao M, Hatakeyama S, Sakaki T et al (2005) Measurement and characterization of C-3 epimerization activity toward vitamin D3. Arch Biochem Biophys 436:196-205. https://doi.org/ 10.1016/j.abb.2005.01.017

30. Astecker N, Satyanarayana Reddy G, Herzig G et al (2000) $1 \alpha, 25$-Dihydroxy-3-epi-vitamin D3 a physiological metabolite of 1 $\alpha, 25$-dihydroxyvitamin D3: its production and metabolism in primary human keratinocytes. Mol Cell Endocrinol 170:91-101. https://doi.org/10.1016/S0303-7207(00)00330-0

31. Lensmeyer G, Poquette M, Wiebe D, Binkley N (2012) The C-3 epimer of 25-hydroxyvitamin D 3 is present in adult serum. $\mathrm{J}$ Clin Endocrinol Metab 97:163-168. https://doi.org/10.1210/jc. 2011-0584

32. Al-Zohily B, Al-Menhali A, Gariballa S et al (2020) Epimers of vitamin d: a review. Int J Mol Sci 21:470. https://doi.org/10. 3390/ijms 21020470

33. Masuda S, Kamao M, Schroeder NJ et al (2000) Characterization of 3-epi-1 $\alpha, 25$-dihydroxyvitamin $\mathrm{d} 3$ involved in $1 \alpha, 25$ dihydroxyvitamin $\mathrm{d} 3$ metabolic pathway in cultured cell lines. Biol Pharm Bull 23:133-139. https://doi.org/10.1248/bpb.23. 133

34. Norman AW, Bouillon R, Farach-Carson MC et al (1993) Demonstration that $1 \beta, 25$-dihydroxyvitamin D3 is an antagonist of the nongenomic but not genomic biological responses and biological profile of the three A-ring diastereomers of $1 \alpha, 25$ dihydroxyvitamin D3. J Biol Chem 268:20022-20030. https:// doi.org/10.1016/s0021-9258(20)80689-9

35. Nakagawa K, Sowa Y, Kurobe M et al (2001) Differential activities of $1 \alpha, 25$-dihydroxy-16-ene-vitamin D3 analogs and their 3-epimers on human promyelocytic leukemia (HL-60) cell differentiation and apoptosis. Steroids 66:327-337

36. Cheng JB, Motola DL, Mangelsdorf DJ, Russell DW (2003) De-orphanization of cytochrome P450 2R1: a microsomal vitamin D 25-hydroxylase. J Biol Chem 278:38084-38093. https:// doi.org/10.1074/jbc.M307028200

37. Holick MF, Binkley NC, Bischoff-Ferrari HA et al (2011) Evaluation, treatment, and prevention of vitamin D deficiency: an endocrine society clinical practice guideline. J Clin Endocrinol Metab 96:1911-1930

38. Powe CE, Evans MK, Wenger J et al (2013) Vitamin D-binding protein and vitamin D status of black Americans and white Americans. N Engl J Med 369:1991-2000. https://doi.org/10. 1056/nejmoa1306357

39. Hannan MT, Litman HJ, Araujo AB et al (2008) Serum 25-hydroxyvitamin $\mathrm{D}$ and bone mineral density in a racially and ethnically diverse group of men. J Clin Endocrinol Metab 93:40-46. https://doi.org/10.1210/jc.2007-1217

40. Bischoff-Ferrari HA, Dietrich T, Orav EJ, Dawson-Hughes B (2004) Positive association between 25-hydroxy vitamin D levels and bone mineral density: a population-based study of younger and older adults. Am J Med 116:634-639. https://doi. org/10.1016/j.amjmed.2003.12.029

41. Cauley JA, Lui LY, Ensrud KE et al (2005) Bone mineral density and the risk of incident nonspinal fractures in black and white women. J Am Med Assoc 293:2102-2108. https://doi. org/10.1001/jama.293.17.2102

42. Cauley JA, Danielson ME, Boudreau R et al (2011) Serum 25-hydroxyvitamin D and clinical fracture risk in a multiethnic cohort of women: the women's health initiative (WHI). J Bone Miner Res 26:2378-2388. https://doi.org/10.1002/jbmr.449

43. Henderson CM, Lutsey PL, Misialek JR et al (2016) Measurement by a novel LC-MS/MS methodology reveals similar serum concentrations of Vitamin D-binding protein in blacks 
and whites. Clin Chem 62:179-187. https://doi.org/10.1373/ clinchem.2015.244541

44. Leong A, Rehman W, Dastani Z et al (2014) The causal effect of vitamin D binding protein (DBP) levels on calcemic and cardiometabolic diseases: a Mendelian randomization study. PLoS Med. https://doi.org/10.1371/JOURNAL.PMED.10017 51

45. Brown LL, Cohen B, Tabor D et al (2018) The vitamin D paradox in Black Americans: a systems-based approach to investigating clinical practice, research, and public health-expert panel meeting report. BMC Proc. https://doi.org/10.1186/ s12919-018-0102-4

46. Zelzer S, Goessler W, Herrmann M (2018) Measurement of vitamin D metabolites by mass spectrometry, an analytical challenge. J Lab Precis Med 3:99-99. https://doi.org/10.21037/jlpm.2018. 11.06

47. Klingberg E, Oleröd G, Konar J et al (2015) Seasonal variations in serum 25-hydroxy vitamin D levels in a Swedish cohort. Endocrine 49:800-808. https://doi.org/10.1007/S12020-015-0548-3

48. Cavalier E, Fraser CG, Bhattoa HP et al (2021) Analytical performance specifications for 25-hydroxyvitamin D examinations. Nutrients 13:431 13-43431. https://doi.org/10.3390/NU130 20431

49. Datta P, Philipsen PA, Olsen P et al (2017) The half-life of $25(\mathrm{OH}) \mathrm{D}$ after UVB exposure depends on gender and vitamin $\mathrm{D}$ receptor polymorphism but mainly on the start level. Photochem Photobiol Sci 16:985-995. https://doi.org/10.1039/C6PP00258G

50. Wielders JPM, Wijnberg FA (2009) Preanalytical stability of $25(\mathrm{OH})$-vitamin D3 in human blood or serum at room temperature: solid as a rock. Clin Chem 55:1584-1585. https://doi.org/ 10.1373/CLINCHEM.2008.117366

51. Cavalier E (2021) Long-term stability of 25-hydroxyvitamin D: Importance of the analytical method and of the patient matrix. Clin Chem Lab Med 59:E389-E391

52. Antoniucci DM, Black DM, Sellmeyer DE (2005) Serum 25-hydroxyvitamin $\mathrm{D}$ is unaffected by multiple freeze-thaw cycles. Clin Chem 51:258-261. https://doi.org/10.1373/CLINC HEM.2004.041954

53. Colak A, Toprak B, Dogan N, Ustuner F (2013) Effect of sample type, centrifugation and storage conditions on vitamin $\mathrm{D}$ concentration. Biochem Medica 23:321-325. https://doi.org/10.11613/ BM.2013.039

54. Lewis JG, Elder PA (2008) Serum 25-OH vitamin D2 and D3 are stable under exaggerated conditions. Clin Chem 54:1931-1932

55. Cavalier E, Lukas P, Bekaert AC et al (2016) Analytical and clinical evaluation of the new Fujirebio Lumipulse ${ }^{\circledR}$ G noncompetitive assay for $25(\mathrm{OH})$-vitamin $\mathrm{D}$ and three immunoassays for 25(OH)D in healthy subjects, osteoporotic patients, third trimester pregnant women, healthy African subjects, hemodia. Clin Chem Lab Med 54:1347-1355. https://doi.org/10.1515/ CCLM-2015-0923

56. Moreau E, Bächer S, Mery S et al (2016) Performance characteristics of the VIDAS ${ }^{\circledR} 25-\mathrm{OH}$ vitamin D total assay-comparison with four immunoassays and two liquid chromatography-tandem mass spectrometry methods in a multicentric study. Clin Chem Lab Med 54:45-53. https://doi.org/10.1515/CCLM-2014-1249/ PDF

57. Tsugawa N, Shiraki M, Suhara Y et al (2008) Low plasma phylloquinone concentration is associated with high incidence of vertebral fracture in Japanese women. J Bone Miner Metab 26:79-85. https://doi.org/10.1007/s00774-007-0790-8

58. Tai SSC, Bedner M, Phinney KW (2010) Development of a candidate reference measurement procedure for the determination of 25-hydroxyvitamin D3 and 25-hydroxyvitamin D 2 in human serum using isotope-dilution liquid chromatography tandem mass spectrometry. Anal Chem 82:1942-1948. https://doi.org/ 10.1021/ac9026862

59. Binkley N, Dawson-Hughes B, Durazo-Arvizu R et al (2017) Vitamin D measurement standardization: the way out of the chaos. J Steroid Biochem Mol Biol 173:117-121. https://doi. org/10.1016/J.JSBMB.2016.12.002

60. Wise SA, Camara JE, Sempos CT et al (2021) Vitamin D standardization program (VDSP) intralaboratory study for the assessment of 25-hydroxyvitamin D assay variability and bias. J Steroid Biochem Mol Biol. https://doi.org/10.1016/J.JSBMB.2021. 105917

61. Volmer DA, Mendes LRBC, Stokes CS (2015) Analysis of vitamin D metabolic markers by mass spectrometry: current techniques, limitations of the "gold standard" method, and anticipated future directions. Mass Spectrom Rev 34:2-23. https://doi. org/10.1002/mas.21408

62. Zhang S, Jian W, Sullivan S et al (2014) Development and validation of an LC-MS/MS based method for quantification of 25 hydroxyvitamin D2 and 25 hydroxyvitamin D3 in human serum and plasma. J Chromatogr B Anal Technol Biomed Life Sci 961:62-70. https://doi.org/10.1016/j.jchromb.2014.05.006

63. Kobold U (2012) Approaches to measurement of Vitamin D concentrations mass spectrometry. Scand J Clin Lab Invest 72:54-59

64. Giuliani S, Barbieri V, Di Pierro AM et al (2019) LC-MS/MS based 25(OH)D status in a large Southern European outpatient cohort: gender- and age-specific differences. Eur J Nutr 58:2511. https://doi.org/10.1007/S00394-018-1803-1

65. Skuladottir SS, Ramel A, Eymundsdottir H et al (2021) Serum 25-hydroxy-vitamin D status and incident hip fractures in elderly adults: looking beyond bone mineral density. J Bone Miner Res. https://doi.org/10.1002/JBMR.4450

66. Wang N, Chen Y, Ji J et al (2020) The relationship between serum vitamin $\mathrm{D}$ and fracture risk in the elderly: a meta-analysis. J Orthop Surg Res. https://doi.org/10.1186/S13018-020-01603-Y

67. Feng Y, Cheng G, Wang H, Chen B (2017) The associations between serum 25-hydroxyvitamin $\mathrm{D}$ level and the risk of total fracture and hip fracture. Osteoporos Int 28:1641-1652. https:// doi.org/10.1007/S00198-017-3955-X

68. Valcour A, Blocki F, Hawkins DM, Rao SD (2012) Effects of age and serum 25-OH-vitamin D on serum parathyroid hormone levels. J Clin Endocrinol Metab 97:3989-3995. https://doi.org/ 10.1210/JC.2012-2276

69. Pilz S, Dobnig H, Fischer JE et al (2008) Low vitamin d levels predict stroke in patients referred to coronary angiography. Stroke 39:2611-2613. https://doi.org/10.1161/STROKEAHA. 107.513655

70. Herrmann M, Sullivan DR, Veillard AS et al (2015) Serum 25-hydroxyvitamin D: a predictor of macrovascular and microvascular complications in patients with type 2 diabetes. Diabetes Care 38:521-528. https://doi.org/10.2337/DC14-0180/-/DC1

71. O'Hartaigh B, Neil Thomas G, Silbernagel G et al (2013) Association of 25-hydroxyvitamin $\mathrm{D}$ with type 2 diabetes among patients undergoing coronary angiography: cross-sectional findings from the LUdwigshafen Risk and Cardiovascular Health (LURIC) study. Clin Endocrinol (Oxf) 79:192-198. https://doi. org/10.1111/CEN.12024

72. Vinh quôc Luong K, Thi Hoàng Nguyên L (2012) Vitamin D and Parkinson's disease. J Neurosci Res 90:2227-2236

73. Harrison SR, Li D, Jeffery LE et al (2020) Vitamin D, autoimmune disease and rheumatoid arthritis. Calcif Tissue Int 106:5875. https://doi.org/10.1007/S00223-019-00577-2

74. Zeng S, Chu C, Doebis C et al (2021) Reference values for free 25-hydroxy-vitamin D based on established total 25-hydroxyvitamin D reference values. J Steroid Biochem Mol Biol 210:105877. https://doi.org/10.1016/j.jsbmb.2021.105877 
75. Ross AC, Manson JAE, Abrams SA et al (2011) The 2011 report on dietary reference intakes for calcium and vitamin $\mathrm{D}$ from the institute of medicine: what clinicians need to know. J Clin Endocrinol Metab 96:53-58. https://doi.org/10.1210/JC.2010-2704

76. Rizzoli R, Boonen S, Brandi ML et al (2013) Vitamin D supplementation in elderly or postmenopausal women: A 2013 update of the 2008 recommendations from the European Society for Clinical and Economic Aspects of Osteoporosis and Osteoarthritis (ESCEO). Curr Med Res Opin 29:305-313

77. Maeda SS, Borba VZC, Camargo MBR et al (2014) Recomendações da Sociedade Brasileira de Endocrinologia e Metabologia (SBEM) para o diagnóstico e tratamento da hipovitaminose D. Arq Bras Endocrinol Metabol 58:411-433. https://doi.org/10. 1590/0004-2730000003388

78. Pérez-López FR, Brincat M, Erel CT et al (2012) EMAS position statement: vitamin D and postmenopausal health. Maturitas 71:83-88. https://doi.org/10.1016/j.maturitas.2011.11.002

79. Aguiar M, Atapattu N, Bhatia V et al (2016) Global consensus recommendations on prevention and management of nutritional rickets. J Clin Endocrinol Metab 101:394-415. https://doi.org/ 10.1210/jc.2015-2175

80. (2014) Recommendations abstracted from the american geriatrics society consensus statement on vitamin D for prevention of falls and their consequences. J Am Geriatr Soc 62:147-152. https:// doi.org/10.1111/jgs.12631

81. Płudowski P, Karczmarewicz E, Bayer M et al (2013) Practical guidelines for the supplementation of vitamin $\mathrm{D}$ and the treatment of defcits in Central Europe-recommended vitamin D intakes in the general population and groups at risk of vitamin D deficiency. Endokrynol Pol 64:319-327. https://doi.org/10.5603/ EP.2013.0012

82. Ramasamy I (2020) Vitamin D metabolism and guidelines for vitamin D supplementation. Clin Biochem Rev 41:103-126

83. Sempos CT, Heijboer AC, Bikle DD et al (2018) Vitamin D assays and the definition of hypovitaminosis $\mathrm{D}$ : results from the first international conference on controversies in vitamin $\mathrm{D}$. Br J Clin Pharmacol 84:2194-2207

84. Souberbielle JC, Deschenes G, Fouque D et al (2016) Recommendations for the measurement of blood 25-OH vitamin D. Ann Biol Clin (Paris) 74:7-19. https://doi.org/10.1684/abc.2015.1107

85. Bikle DD, Schwartz J (2019) Vitamin D binding protein, total and free vitamin D levels in different physiological and pathophysiological conditions. Front Endocrinol (Lausanne) 10:317. https://doi.org/10.3389/FENDO.2019.00317/BIBTEX

86. Roizen JD, Casella A, Lai M et al (2018) Decreased serum 25-hydroxyvitamin $\mathrm{D}$ in aging male mice is associated with reduced hepatic Cyp2r1 abundance. Endocrinology 159:30833089. https://doi.org/10.1210/en.2017-03028

87. Roizen JD, Long C, Casella A et al (2019) Obesity Decreases hepatic 25-hydroxylase activity causing low serum 25-hydroxyvitamin D. J Bone Miner Res 34:1068-1073. https://doi.org/10. 1002/jbmr.3686

88. Aatsinki S-M, Elkhwanky M-S, Kummu O et al (2019) Fastinginduced transcription factors repress vitamin D bioactivation, a mechanism for vitamin d deficiency in diabetes. Diabetes 68:918-931. https://doi.org/10.2337/DB18-1050

89. Best CM, Pressman EK, Queenan RA et al (2019) Longitudinal changes in serum vitamin $\mathrm{D}$ binding protein and free 25-hydroxyvitamin $\mathrm{D}$ in a multiracial cohort of pregnant adolescents. J Steroid Biochem Mol Biol 186:79-88. https://doi.org/10.1016/j. jsbmb.2018.09.019

90. Moon RJ, Crozier SR, Dennison EM et al (2015) Tracking of 25-hydroxyvitamin D status during pregnancy: the importance of vitamin D supplementation. Am J Clin Nutr 102:1081-1087. https://doi.org/10.3945/AJCN.115.115295
91. Papapetrou PD (2010) The interrelationship of serum 1,25-dihydroxyvitamin D, 25-hydroxyvitamin D and 24,25-dihydroxyvitamin $\mathrm{D}$ in pregnancy at term: a meta-analysis. Hormones (Athens) 9:136-144. https://doi.org/10.14310/HORM.2002.1263

92. Figueiredo ACC, Cocate PG, Adegboye ARA et al (2018) Changes in plasma concentrations of 25-hydroxyvitamin D and 1,25-dihydroxyvitamin D during pregnancy: a Brazilian cohort. Eur J Nutr 57:1059-1072. https://doi.org/10.1007/ s00394-017-1389-Z

93. Park H, Wood MR, Malysheva OV et al (2017) Placental vitamin $\mathrm{D}$ metabolism and its associations with circulating vitamin $\mathrm{D}$ metabolites in pregnant women. Am J Clin Nutr 106:1439-1487. https://doi.org/10.3945/ajcn

94. Kovacs CS (2014) Bone development and mineral homeostasis in the fetus and neonate: roles of the calciotropic and phosphotropic hormones. Physiol Rev 94:1143-1218. https://doi.org/10.1152/ PHYSREV.00014.2014

95. Melamed ML, Chonchol M, Gutiérrez OM et al (2018) The role of vitamin D in CKD stages 3 to 4: report of a scientific workshop sponsored by the national kidney foundation. Am J Kidney Dis 72:834-845

96. Ali FN, Arguelles LM, Langman CB, Price HE (2009) Vitamin D deficiency in children with chronic kidney disease: uncovering an epidemic. Pediatrics 123:791-796. https://doi.org/10.1542/ peds.2008-0634

97. Christodoulou M, Aspray TJ, Schoenmakers I (2021) Vitamin D supplementation for patients with chronic kidney disease: a systematic review and meta-analyses of trials investigating the response to supplementation and an overview of guidelines. Calcif Tissue Int 109:157-178. https://doi.org/10.1007/S00223-02100844-1/FIGURES/4

98. Johnson JM, Maher JW, DeMaria EJ et al (2006) The long-term effects of gastric bypass on vitamin D metabolism. Ann Surg 243:701. https://doi.org/10.1097/01.SLA.0000216773.47825.C1

99. Schafer AL (2017) Vitamin D and intestinal calcium transport after bariatric surgery. J Steroid Biochem Mol Biol 173:202-210. https://doi.org/10.1016/J.JSBMB.2016.12.012

100. Borges JLC, de Miranda IS, Sarquis MMS et al (2018) Obesity, bariatric surgery, and vitamin D. J Clin Densitom 21:157-162. https://doi.org/10.1016/J.JOCD.2017.03.001

101. Manson JE, Cook NR, Lee I-M et al (2019) Marine $n-3$ fatty acids and prevention of cardiovascular disease and cancer. $\mathrm{N}$ Engl J Med 380:23-32. https://doi.org/10.1056/nejmoa1811403

102. Scragg R, Stewart AW, Waayer D et al (2017) Effect of monthly high-dose vitamin D supplementation on cardiovascular disease in the vitamin D assessment study: a randomized clinical trial. JAMA Cardiol 2:608-616. https://doi.org/10.1001/jamacardio. 2017.0175

103. Pilz S, Trummer C, Theiler-Schwetz V et al (2022) Critical appraisal of large vitamin D randomized controlled trials. Nutrients 14:303

104. Autier P, Boniol M, Pizot C, Mullie P (2014) Vitamin D status and ill health: a systematic review. Lancet Diabetes Endocrinol 2:76-89. https://doi.org/10.1016/S2213-8587(13)70165-7

105. Bae JH, Choe HJ, Holick MF, Lim S (2022) Association of vitamin D status with COVID-19 and its severity: vitamin D and COVID-19: a narrative review. Rev Endocr Metab Disord 1:1-21. https://doi.org/10.1007/s11154-021-09705-6

106. Zelzer S, Prüller F, Curcic P et al (2021) Vitamin D metabolites and clinical outcome in hospitalized COVID-19 patients. Nutrients 13:2129. https://doi.org/10.3390/nu13072129

107. Hewison M, Burke F, Evans KN et al (2007) Extra-renal 25-hydroxyvitamin D3-1 $\alpha$-hydroxylase in human health and disease. J Steroid Biochem Mol Biol 103:316-321. https://doi. org/10.1016/j.jsbmb.2006.12.078 
108. Myrtle JF, Norman AW (1971) Vitamin D: A cholecalciferol metabolite highly active in promoting intestinal calcium transport. Science 171:79-82. https://doi.org/10.1126/science.171. 3966.79

109. Mizwicki MT, Bula CM, Bishop JE, Norman AW (2005) A perspective on how the vitamin D sterol/vitamin D receptor (VDR) conformational ensemble model can potentially be used to understand the structure-function results of A-ring modified Vitamin D sterols. J Steroid Biochem Mol Biol 97:69-82

110. Ralston SH, Uitterlinden AG (2010) Genetics of osteoporosis. Endocr Rev 31:629-662

111. Altieri B, Grant WB, Della Casa S et al (2017) Vitamin D and pancreas: the role of sunshine vitamin in the pathogenesis of diabetes mellitus and pancreatic cancer. Crit Rev Food Sci Nutr 57:3472-3488. https://doi.org/10.1080/10408398.2015.1136922

112. Tirabassi G, Salvio G, Altieri B et al (2017) Adrenal disorders: is there Any role for vitamin D? Rev Endocr Metab Disord $18: 355-362$

113. Muscogiuri G, Altieri B, de Angelis C et al (2017) Shedding new light on female fertility: the role of vitamin D. Rev Endocr Metab Disord 18:273-283. https://doi.org/10.1007/S11154-017-9407-2

114. Seamans KM, Cashman KD (2009) Existing and potentially novel functional markers of vitamin D status: a systematic review. Am J Clin Nutr. https://doi.org/10.3945/ajcn.2009. 27230D

115. Chapuy MC, Chapuy P, Meunier PJ (1987) Calcium and vitamin D supplements: effects on calcium metabolism in elderly people. Am J Clin Nutr 46:324-328. https://doi.org/10.1093/ AJCN/46.2.324

116. Barger-Lux MJ, Heaney RP, Dowell S et al (1998) Vitamin D and its major metabolites: serum levels after graded oral dosing in healthy men. Osteoporos Int 8:222-230. https://doi.org/10. 1007/S001980050058

117. Vieth R, Ladak Y, Walfish PG (2003) Age-related changes in the 25-hydroxyvitamin $\mathrm{D}$ versus parathyroid hormone relationship suggest a different reason why older adults require more vitamin D. J Clin Endocrinol Metab 88:185-191. https://doi. org/10.1210/JC.2002-021064

118. Vaes AMM, Tieland M, de Regt MF et al (2018) Doseresponse effects of supplementation with calcifediol on serum 25-hydroxyvitamin D status and its metabolites: a randomized controlled trial in older adults. Clin Nutr 37:808-814. https:// doi.org/10.1016/j.clnu.2017.03.029

119. Saponaro F, Saba A, Zucchi R (2020) An update on vitamin d metabolism. Int J Mol Sci 21:1-19

120. Lee SM, Riley EM, Meyer MB et al (2015) 1,25-Dihydroxyvitamin D3 controls a cohort of vitamin D receptor target genes in the proximal intestine that is enriched for calcium-regulating components. J Biol Chem 290:18199-18215. https://doi.org/ 10.1074/JBC.M115.665794

121. Goltzman D (2018) Functions of vitamin D in bone. Histochem Cell Biol 149:305-312

122. Sonoda J, Pei L, Evans RM (2008) Nuclear receptors: decoding metabolic disease. FEBS Lett 582:2-9

123. Goltzman D, Mannstadt M, Marcocci C (2018) Physiology of the calcium-parathyroid hormone-vitamin D axis. Front Horm Res 50:1-13. https://doi.org/10.1159/000486060

124. van de Peppel J, van Leeuwen JPTM (2014) Vitamin D and gene networks in human osteoblasts. Front Physiol. https://doi. org/10.3389/fphys.2014.00137

125. Suda T, Takahashi N, Abe E (1992) Role of vitamin D in bone resorption. J Cell Biochem 49:53-58. https://doi.org/10.1002/ jcb. 240490110

126. Holick MF (2010) Vitamin D: evolutionary, physiological and health perspectives. Curr Drug Targets 12:4-18. https://doi. org/10.2174/138945011793591635
127. Yang R, Chen J, Zhang J et al (2020) 1,25-Dihydroxyvitamin D protects against age-related osteoporosis by a novel VDREzh2-p16 signal axis. Aging Cell. https://doi.org/10.1111/ ACEL.13095

128. Chen L, Yang R, Qiao W et al (2019) 1,25-Dihydroxyvitamin D exerts an antiaging role by activation of Nrf2-antioxidant signaling and inactivation of p16/p53-senescence signaling. Aging Cell. https://doi.org/10.1111/acel.12951

129. Colotta F, Jansson B, Bonelli F (2017) Modulation of inflammatory and immune responses by vitamin D. J Autoimmun 85:78-97

130. Munger KL, Levin LI, Hollis BW et al (2006) Serum 25-hydroxyvitamin D levels and risk of multiple sclerosis. J Am Med Assoc 296:2832-2838. https://doi.org/10.1001/jama.296.23.2832

131. Kautzky-willer A, Pacini G, Barnas U, et al (1995) Intravenous calcitriol normalizes insulin sensitivity in uremic patients. Kidney Int 47:200-206. https://doi.org/10.1038/ki.1995.24

132. Bricio-Barrios JA, Palacios-Fonseca AJ, del Toro-Equihua M, Sanchez-Ramirez CA (2016) Effect of calcitriol supplementation on blood pressure in older adults. J Nutr Gerontol Geriatr 35:243-252. https://doi.org/10.1080/21551197.2016.1206499

133. Ashraf A, Alvarez JA (2010) Role of vitamin D in insulin secretion and insulin sensitivity for glucose homeostasis. Int J Endocrinol. https://doi.org/10.1155/2010/351385

134. Wang TJ (2016) Vitamin D and cardiovascular disease. Annu Rev Med 67:261-272. https://doi.org/10.1146/annur ev-med-051214-025146

135. Thomas RL, Jiang L, Adams JS et al (2020) Vitamin D metabolites and the gut microbiome in older men. Nat Commun 11:110. https://doi.org/10.1038/s41467-020-19793-8

136. Ooi JH, Li Y, Rogers CJ, Cantorna MT (2013) Vitamin D regulates the gut microbiome and protects mice from dextran sodium sulfate-induced coliti. J Nutr 143:1679-1686. https://doi.org/10. 3945/jn.113.180794

137. Davies M, Heys SE, Selby PL et al (1997) Increased catabolism of 25-hydroxyvitamin D in patients with partial gastrectomy and elevated 1,25-dihydroxyvitamin D levels. Implications for metabolic bone disease. J Clin Endocrinol Metab 82:209-212. https:// doi.org/10.1210/JCEM.82.1.3644

138. Brumbaugh PF, Haussler DH, Bressler R, Haussler MR (1974) Radioreceptor assay for 1 alpha,25-dihydroxyvitamin D3. Science 183:1089-1091. https://doi.org/10.1126/SCIENCE.183. 4129.1089

139. Dokoh S, Morita R, Fukunaga M et al (1978) Competitive protein binding assay for 1,25-dihydroxy-vitamin $\mathrm{D}$ in human plasma. Endocrinol Jpn 25:431-436. https://doi.org/10.1507/ENDOC RJ1954.25.431

140. Peacock M, Taylor GA, Brown W (1980) Plasma 1,25(OH)2 vitamin D measured by radioimmunoassay and cytosol radioreceptor assay in normal subjects and patients with primary hyperparathyroidism and renal failure. Clin Chim Acta 101:93-101. https:// doi.org/10.1016/0009-8981(80)90060-1

141. Hussein H, Ibrahim F, Boudou P (2015) Evaluation of a new automated assay for the measurement of circulating 1,25-dihydroxyvitamin D levels in daily practice. Clin Biochem 48:11601162. https://doi.org/10.1016/j.clinbiochem.2015.05.018

142. Dabek JT, Harkonen M, Wahlroos AH (1981) Assay for plasma 25-hydroxyvitamin D2 and 25-hydroxyvitamin D3 by "highperformance" liquid chromatography. Clin Chem 27:1346-1351

143. Eisman JA, Shepard RM, DeLuca HF (1977) Determination of 25-hydroxyvitamin D2 and 25-hydroxyvitamin D3 in human plasma using high-pressure liquid chromatography. Anal Biochem 80:298-305. https://doi.org/10.1016/0003-2697(77) 90648-0

144. Jones G (1978) Assay of vitamins D2 and D3, and 25-hydroxyvitamins D2 and D3 in human plasma by high-performance liquid 
chromatography. Clin Chem 24:287-298. https://doi.org/10. 1093/CLINCHEM/24.2.287

145. Oftebro H, Falch JA, Holmberg I, Haug E (1988) Validation of a radioreceptor assay for 1,25-dihydroxyvitamin $\mathrm{D}$ using selected ion monitoring GC-MS. Clin Chim Acta 176:157-168. https:// doi.org/10.1016/0009-8981(88)90203-3

146. Maunsell Z, Wright DJ, Rainbow SJ (2005) Routine isotopedilution liquid chromatography-tandem mass spectrometry assay for simultaneous measurement of the 25-hydroxy metabolites of vitamins D2 and D3. Clin Chem 51:1683-1690. https://doi.org/ 10.1373/CLINCHEM.2005.052936

147. Tsugawa N, Okano T (2006) Bone and bone related biochemical examinations. Hormone and hormone related substances. Vitamin $\mathrm{D}(25 \mathrm{D}, 1,25 \mathrm{D})$; measurements and clinical significances. Clin Calcium 16:36-42

148. Hollis BW, Horst RL (2007) The assessment of circulating 25(OH)D and 1,25(OH)2D: where we are and where we are going. J Steroid Biochem Mol Biol 103:473. https://doi.org/10. 1016/J.JSBMB.2006.11.00

149. Valcour A, Zierold C, Podgorski AL et al (2016) A novel, fully-automated, chemiluminescent assay for the detection of 1,25-dihydroxyvitamin D in biological samples. J Steroid Biochem Mol Biol 164:120-126. https://doi.org/10.1016/J.JSBMB. 2015.08.005

150. Zittermann A, Ernst JB, Becker T et al (2016) Measurement of circulating 1,25-Dihydroxyvitamin D: comparison of an automated method with a liquid chromatography tandem mass spectrometry method. Int J Anal Chem 2016:25. https://doi.org/10. $1155 / 2016 / 8501435$

151. Dirks NF, Ackermans MT, Lips P et al (2018) The when, what \& how of measuring vitamin D metabolism in clinical medicine. Nutrients. https://doi.org/10.3390/NU10040482

152. Zittermann A, Ernst JB, Becker T et al (2016) Measurement of circulating 1,25-Dihydroxyvitamin D: comparison of an automated method with a liquid chromatography tandem mass spectrometry method. Int J Anal Chem. https://doi.org/10.1155/2016/ 8501435

153. Strathmann FG, Laha TJ, Hoofnagle AN (2011) Quantification of $1 \alpha, 25$-dihydroxy vitamin $\mathrm{D}$ by immunoextraction and liquid chromatography-tandem mass spectrometry. Clin Chem 57:1279-1285. https://doi.org/10.1373/CLINCHEM.2010. 161174

154. Pauwels S, Jans I, Billen J et al (2017) 1 13,25-Dihydroxyvitamin D3: a new vitamin D metabolite in human serum. J Steroid Biochem Mol Biol 173:341-348. https://doi.org/10.1016/j.jsbmb. 2017.02.004

155. Dirks NF, Martens F, Vanderschueren D et al (2016) Determination of human reference values for serum total 1,25-dihydroxyvitamin D using an extensively validated 2D ID-UPLC-MS/MS method. J Steroid Biochem Mol Biol 164:127-133

156. Higgins V, Truong D, White-Al Habeeb NMA et al (2018) Pediatric reference intervals for 1,25-dihydroxyvitamin D using the DiaSorin LIAISON XL assay in the healthy CALIPER cohort. Clin Chem Lab Med 56:964-972. https://doi.org/10.1515/ cclm-2017-0767

157. Taylor-Miller T, Allgrove J (2021) Endocrine diseases of newborn: epidemiology, pathogenesis, therapeutic options, and outcome "current insights into disorders of calcium and phosphate in the newborn." Front Pediatr 9:42

158. Taylor-Miller T, Allgrove J (2021) Endocrine diseases of newborn: Epidemiology, pathogenesis, therapeutic options, and outcome "Current Insights Into Disorders of Calcium and Phosphate in the Newborn." Front Pediatr 9:600490. https://doi.org/ 10.3389/fped.2021.600490
159. Jean G, Souberbielle JC, Chazot C (2017) Vitamin D in chronic kidney disease and dialysis patients. Nutrients 9:328

160. Glass AR, Cerletty JM, Elliott W et al (1990) Ketoconazole reduces elevated serum levels of 1,25-dihydroxyvitamin D in hypercalcemic sarcoidosis. J Endocrinol Invest 13:407-413. https://doi.org/10.1007/BF03350691

161. Saggese G, Bertelloni S, Baroncelli GI, Nero G (1993) Ketoconazole decreases the serum ionized calcium and 1,25-dihydroxyvitamin D levels in tuberculosis-associated hypercalcemia. Am J Dis Child 147:270-273. https://doi.org/10.1001/ARCHPEDI. 1993.02160270032013

162. Ganguly A, Tamblyn JA, Finn-Sell S et al (2018) Vitamin D, the placenta and early pregnancy: effects on trophoblast function. J Endocrinol 236:R93-R103. https://doi.org/10.1530/JOE-17-0491

163. Kleerekoper M, Nelson DA, Peterson EL et al (1994) Reference data for bone mass, calciotropic hormones, and biochemical markers of bone remodeling in older (55-75) postmenopausal white and black women. J Bone Miner Res 9:1267-1276. https:// doi.org/10.1002/JBMR.5650090817

164. Bikle DD, Ettinger B, Sidney S et al (1999) Differences in calcium metabolism between black and white men and women. Miner Electrolyte Metab 25:178-184. https://doi.org/10.1159/ 000057442

165. Aloia J, Mikhail M, Dhaliwal R et al (2015) Free 25(OH)D and the vitamin D paradox in African Americans. J Clin Endocrinol Metab 100:3356-3363. https://doi.org/10.1210/JC.2015-2066

166. Schmitt CP, Mehls O (2004) The enigma of hyperparathyroidism in hypophosphatemic rickets. Pediatr Nephrol 19:473-477. https://doi.org/10.1007/S00467-004-1443-Y

167. De Boer IH, Sachs MC, Chonchol M et al (2014) Estimated GFR and circulating 24,25-dihydroxyvitamin D3 concentration: a participant-level analysis of 5 cohort studies and clinical trials. Am J Kidney Dis 64:187-197. https://doi.org/10.1053/j.ajkd.2014.02. 015

168. Berg AH, Powe CE, Evans MK et al (2015) 24,25-dihydroxyvitamin D3and vitamin D status of community-dwelling black and white Americans. Clin Chem 61:877-884. https://doi.org/ 10.1373/clinchem.2015.240051

169. Schlingmann KP, Kaufmann M, Weber S et al (2011) Mutations in CYP24A1 and idiopathic infantile hypercalcemia. N Engl J Med 365:410-421. https://doi.org/10.1056/nejmoa1103864

170. Herrmann M (2019) Towards a personalized assessment of vitamin D status. Clin Chem Lab Med. https://doi.org/10.1515/ CCLM-2019-1213

171. Ginsberg C, Katz R, de Boer IH et al (2018) The 24,25 to 25-hydroxyvitamin $\mathrm{D}$ ratio and fracture risk in older adults: the cardiovascular health study. Bone 107:124-130. https://doi.org/ 10.1016/j.bone.2017.11.011

172. Bosworth CR, Levin G, Robinson-Cohen C et al (2012) The serum 24,25-dihydroxyvitamin D concentration, a marker of vitamin D catabolism, is reduced in chronic kidney disease. Kidney Int 82:693-700. https://doi.org/10.1038/ki.2012.193

173. Wagner D, Hanwell HE, Schnabl K et al (2011) The ratio of serum 24,25-dihydroxyvitamin $\mathrm{D}(3)$ to 25 -hydroxyvitamin $\mathrm{D}(3)$ is predictive of 25-hydroxyvitamin $\mathrm{D}(3)$ response to vitamin $\mathrm{D}$ (3) supplementation. J Steroid Biochem Mol Biol 126:72-77. https://doi.org/10.1016/J.JSBMB.2011.05.003

174. Francic V, Ursem SR, Dirks NF et al (2019) The effect of vitamin D supplementation on its metabolism and the vitamin D metabolite ratio. Nutrients. https://doi.org/10.3390/nu11102539

175. Lehmann U, Riedel A, Hirche F et al (2016) Vitamin D3 supplementation: response and predictors of vitamin D3 metabolites-a randomized controlled trial. Clin Nutr 35:351-358. https://doi. org/10.1016/j.clnu.2015.04.021 
176. Aloia J, Fazzari M, Shieh A et al (2017) The vitamin D metabolite ratio (VMR) as a predictor of functional biomarkers of bone health. Clin Endocrinol (Oxf) 86:674-679. https://doi.org/10. 1111/cen.13319

177. Mena-Bravo A, Calderón-Santiago M, Luque de Castro MD, Priego-Capote F (2019) Evaluation of short-term storage prior to analysis of vitamin D3 and metabolites in human serum by liquid chromatography coupled to tandem mass spectrometry. Talanta 198:344-349. https://doi.org/10.1016/J.TALANTA.2019.02.030

178. Wise SA, Phinney KW, Tai SSC et al (2017) Baseline assessment of 25-hydroxy vitamin D assay performance: a vitamin D standardization program (VDSP) interlaboratory comparison study. J AOAC Int 100:1244-1252

179. Tai SSC, Nelson MA, Bedner M et al (2017) Development of standard reference material (SRM) 2973 vitamin D metabolites in frozen human serum (High Level). J AOAC Int 100:12941303. https://doi.org/10.5740/JAOACINT.17-0182

180. Phinney KW, Tai SSC, Bedner M et al (2017) Development of an improved standard reference material for vitamin D metabolites in human serum. Anal Chem 89:4907-4913. https://doi.org/10. 1021/acs.analchem.6b05168

181. Tai SSC, Nelson MA (2015) Candidate reference measurement procedure for the determination of (24R),25-dihydroxyvitamin D3 in human serum using isotope-dilution liquid chromatography-tandem mass spectrometry. Anal Chem 87:7964-7970. https://doi.org/10.1021/ACS.ANALCHEM.5B01861

182. Carter GD, Ahmed F, Berry J et al (2019) External quality assessment of 24,25-dihydroxyvitamin D $3(24,25(\mathrm{OH}) 2 \mathrm{D} 3)$ assays. J Steroid Biochem Mol Biol 187:130-133. https://doi.org/ 10.1016/j.jsbmb.2018.11.010

183. Dirks NF, Ackermans MT, De Jonge R, Heijboer AC (2019) Reference values for 24,25-dihydroxyvitamin $\mathrm{D}$ and the 25-hydroxyvitamin D/24,25-dihydroxyvitamin D ratio. Clin Chem Lab Med. https://doi.org/10.1515/cclm-2018-1096

184. Tang JCY, Nicholls H, Piec I et al (2017) Reference intervals for serum 24,25-dihydroxyvitamin D and the ratio with 25-hydroxyvitamin D established using a newly developed LC-MS/MS method. J Nutr Biochem 46:21-29. https://doi.org/10.1016/j. jnutbio.2017.04.005

185. Ketha H, Kumar R, Singh RJ (2016) LC-MS/MS for identifying patients with CYP24A1 mutations. Clin Chem 62:236-242. https://doi.org/10.1373/clinchem.2015.244459

186. Cooke NE, McLeod JF, Wang X, Ray K (1991) Vitamin D binding protein: genomic structure, functional domains, and mRNA expression in tissues. J Steroid Biochem Mol Biol 40:787-793. https://doi.org/10.1016/0960-0760(91)90304-N

187. Nykjaer A, Dragun D, Walther D et al (1999) An endocytic pathway essential for renal uptake and activation of the steroid 25-(OH) vitamin D3. Cell 96:507-515. https://doi.org/10.1016/ S0092-8674(00)80655-8

188. Henderson CM, Fink SL, Bassyouni H et al (2019) Vitamin D-binding protein deficiency and homozygous deletion of the GC gene. N Engl J Med 380:1150-1157. https://doi.org/10.1056/ nejmoa1807841

189. Safadi FF, Thornton P, Magiera H et al (1999) Osteopathy and resistance to vitamin $\mathrm{D}$ toxicity in mice null for vitamin $\mathrm{D}$ binding protein. J Clin Invest 103:239-251. https://doi.org/10.1172/ JCI5244

190. Bikle DD (2021) The free hormone hypothesis: when, why, and how to measure the free hormone levels to assess vitamin D, thyroid, sex hormone, and cortisol status. JBMR Plus. https:// doi.org/10.1002/jbm4.10418

191. Lefevre ML, Siu AL, Bibbins-Domingo K et al (2015) Screening for vitamin D deficiency in adults: U.S. Preventive services task force recommendation statement. Ann Intern Med 162:133-140. https://doi.org/10.7326/M14-2450

192. Bikle DD, Halloran BP, Gee E et al (1986) Free 25-hydroxyvitamin D levels are normal in subjects with liver disease and reduced total 25-hydroxyvitamin D levels. J Clin Invest 78:748752. https://doi.org/10.1172/JCI112636

193. Schwartz JB, Christopher Gallagher J, Jorde R et al (2018) Determination of Free 25(OH)D concentrations and their relationships to total $25(\mathrm{OH}) \mathrm{D}$ in multiple clinical populations. J Clin Endocrinol Metab 103:3278-3288. https://doi.org/10.1210/ jc.2018-00295

194. Martin CB, Oshiro BT, Sands LAD et al (2020) Vitamin-D dysregulation in early- and late-onset preeclampsia: a gestational-age matched study. J Steroid Biochem Mol Biol. https://doi.org/10. 1016/J.JSBMB.2020.105729

195. Lundgren S, Carling T, Hjälm G et al (1997) Tissue distribution of human gp330/megalin, a putative $\mathrm{Ca}(2+)$-sensing protein. J Histochem Cytochem 45:383-392. https://doi.org/10.1177/00221 5549704500306

196. Zheng G, Bachinsky DR, Stamenkovic I et al (1994) Organ distribution in rats of two members of the low-density lipoprotein receptor gene family, gp330 and LRP/alpha 2MR, and the receptor-associated protein (RAP). J Histochem Cytochem 42:531-542. https://doi.org/10.1177/42.4.7510321

197. Bhan I, Powe CE, Berg AH et al (2012) Bioavailable vitamin D is more tightly linked to mineral metabolism than total vitamin D in incident hemodialysis patients. Kidney Int 82:84-89. https:// doi.org/10.1038/ki.2012.19

198. Rivera-Paredez B, Hidalgo-Bravo A, León-Reyes G et al (2021) Total, bioavailable, and free 25 -hydroxyvitamin D equally associate with adiposity markers and metabolic traits in mexican adults. Nutrients. https://doi.org/10.3390/NU13103320/S1

199. Heo YJ, Lee YJ, Lee K et al (2021) Total, bioavailable and free 25-hydroxyvitamin D levels as functional indicators for bone parameters in healthy children. PLoS ONE 16:e258585. https:// doi.org/10.1371/JOURNAL.PONE.0258585

200. Rockwell MS, Kostelnik SB, McMillan RP, Lancaster M, Enette Larson-Meyer D, Hulver MW (2021) An association between bioavailable 25-hydroxyvitamin $\mathrm{D}$ and bone mineral density in a diverse cohort of collegiate athletes. Med Sci Sports Exerc. https://doi.org/10.1249/MSS.0000000000002807

201. Bikle DD, Gee E, Halloran B et al (1986) Assessment of the free fraction of 25-hydroxyvitamin $\mathrm{d}$ in serum and its regulation by albumin and the vitamin d-binding protein. J Clin Endocrinol Metab 63:954-959. https://doi.org/10.1210/jcem-63-4-954

202. Arnaud J, Constans J (1993) Affinity differences for vitamin D metabolites associated with the genetic isoforms of the human serum carrier protein (DBP). Hum Genet 92:183-188. https:// doi.org/10.1007/BF00219689

203. Lauridsen AL, Vestergaard P, Nexo E (2001) Mean serum concentration of vitamin D-binding protein ( $\mathrm{Gc}$ globulin) is related to the Gc phenotype in women. Clin Chem 47:753-756. https:// doi.org/10.1093/clinchem/47.4.753

204. Fu L, Yun F, Oczak M et al (2009) Common genetic variants of the vitamin D binding protein (DBP) predict differences in response of serum 25-hydroxyvitamin D [25(OH)D] to vitamin D supplementation. Clin Biochem 42:1174-1177. https://doi.org/ 10.1016/J.CLINBIOCHEM.2009.03.008

205. Takiar R, Lutsey PL, Zhao D et al (2015) The associations of 25-hydroxyvitamin D levels, vitamin D binding protein gene polymorphisms, and race with risk of incident fracture-related hospitalization: twenty-year follow-up in a bi-ethnic cohort (the ARIC Study). Bone 78:94-101. https://doi.org/10.1016/J.BONE. 2015.04.029 
206. Malik S, Fu L, Juras DJ et al (2013) Common variants of the vitamin $\mathrm{D}$ binding protein gene and adverse health outcomes. Crit Rev Clin Lab Sci 50:1-22. https://doi.org/10.3109/10408 363.2012.750262

207. Speeckaert M, Huang G, Delanghe JR, Taes YEC (2006) Biological and clinical aspects of the vitamin $\mathrm{D}$ binding protein (Gc-globulin) and its polymorphism. Clin Chim Acta 372:33-42. https://doi.org/10.1016/J.CCA.2006.03.011

208. Makris K, Bhattoa HP, Cavalier E et al (2021) Recommendations on the measurement and the clinical use of vitamin D metabolites and vitamin D binding protein - a position paper from the IFCC Committee on bone metabolism. Clin Chim Acta 517:171-197. https://doi.org/10.1016/j.cca.2021.03.002

209. Denburg MR, Hoofnagle AN, Sayed S et al (2016) Comparison of two ELISA methods and mass spectrometry for measurement of vitamin D-binding protein: implications for the assessment of bioavailable vitamin d concentrations across genotypes. J Bone Miner Res 31:1128-1136. https://doi.org/10.1002/jbmr.2829

210. Hollis BW, Bikle DD (2014) Vitamin D-binding protein and vitamin D in blacks and whites. N Engl J Med 370:878-881. https:// doi.org/10.1056/nejmc1315850

211. Nielson CM, Jones KS, Chun RF et al (2016) Role of assay type in determining free 25-hydroxyvitamin $\mathrm{D}$ levels in diverse populations. N Engl J Med 374:1695-1696. https://doi.org/10.1056/ nejmc1513502

212. Bikle DD, Siiteri PK, Ryzen E et al (1985) Serum protein binding of 1,25-Dihydroxyvitamin D: a reevaluation by direct measurement of free metabolite levels. J Clin Endocrinol Metab 61:969975. https://doi.org/10.1210/jcem-61-5-969

213. Heureux N, Lindhout E, Swinkels L (2017) A direct assay for measuring free 25-hydroxyvitamin D. J AOAC Int 100:1318-1322

214. Peris P, Filella X, Monegal A et al (2017) Concordance between direct and indirect measurements of free $25-\mathrm{OH}$ vitamin $\mathrm{D}$. Clin Chim Acta 475:169-171. https://doi.org/10.1016/j.cca.2017.10. 016

215. Lopez-Molina M, Santillan C, Murillo M et al (2018) Measured free 25-hydroxyvitamin D in healthy children and relationship to total 25-hydroxyvitamin D, calculated free 25-hydroxyvitamin D and vitamin D binding protein. Clin Biochem 61:23-27. https:// doi.org/10.1016/J.CLINBIOCHEM.2018.08.007

216. Jukic AMZ, Hoofnagle AN, Lutsey PL (2018) Measurement of vitamin D for Epidemiologic and clinical research: shining light on a complex decision. Am J Epidemiol 187:879-890

217. Kennel KA, Drake MT, Hurley DL (2010) Vitamin D deficiency in adults: when to test and how to treat. Mayo Clin Proc 85:752-758

218. Heijboer AC, Blankenstein MA, Kema IP, Buijs MM (2012) Accuracy of 6 routine 25-hydroxyvitamin D assays: influence of vitamin D binding protein concentration. Clin Chem 58:543-548. https://doi.org/10.1373/clinchem.2011.176545

219. Kim HJ, Ji M, Song J et al (2017) Clinical utility of measurement of vitamin D-binding protein and calculation of bioavailable vitamin D in assessment of vitamin D status. Ann Lab Med 37:34-38. https://doi.org/10.3343/alm.2017.37.1.34

220. Jeng L, Yamshchikov AV, Judd SE et al (2009) Alterations in vitamin $\mathrm{D}$ status and anti-microbial peptide levels in patients in the intensive care unit with sepsis. J Transl Med 7:1-9. https:// doi.org/10.1186/1479-5876-7-28

221. Dahl B, Schiødt FV, Ott P et al (2003) Plasma concentration of Gc-globulin is associated with organ dysfunction and sepsis after injury. Crit Care Med 31:152-156. https://doi.org/10.1097/00003 246-200301000-00024

222. van Hoof HJC, de Sévaux RGL, van Baelen H et al (2001) Relationship between free and total 1,25-dihydroxyvitamin D in conditions of modified binding. Eur J Endocrinol 144:391-396. https://doi.org/10.1530/eje.0.1440391

Publisher's Note Springer Nature remains neutral with regard to jurisdictional claims in published maps and institutional affiliations. 